\title{
咬合挙上が咀嚼筋に及ぼす影響に関する実験的研究
}

\author{
赤川安正 \\ Experimental Studies on Masticatory Muscle \\ Changes under Bite Raising
}

\section{Yasumasa Akagawa}

\section{緒 言}

最近, 補緅臨床において, oral rehabilitation を必 要とする症例や咬合の異常に起因する䫑関節症が注目さ れ，これらの症例では，咬合の修正，とりわけ咬合挙上 を行うことによって咬合の再構成を図る機会が増加して いる1 ${ }^{1 \sim 4}$. したがって，咬合挙上に対する影口腔組織の 反応を明らかにすることは，正確な診断を下し，適切な 補緅治療を行う上に重要な意義を有している.

従来の咬合挙上に関する研究は，主として機能的立場 からなされ，とりわけ咀徱筋活動に対する影響が検索さ れてきた ${ }^{5-11)}$ 。たとえば，Christensen ${ }^{6)}$ は顎口腔の諸 組織が予想以上に順応することを認めながらも，咀嚼筋 に連続的な圧迫感や疼痛をきたすことを報告しており， また，Drechsler ${ }^{7}$ は咬筋 EMG 放電の消長に，小泉 ${ }^{9}$ は 咬筋のパワースペクトルの変化にそれぞれ注目してい る.しかしながら，咬合挙上が咀徱筋に及ぼす影響を 形態学的立場から追求した研究はきわめて少ないうえ

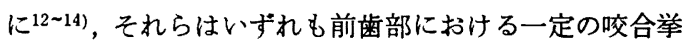
上量に対する咬筋および側頭筋の組織学的変化を観察し たにすぎず，咀嚼機能の面でより重視すべき臼歯部での 咬合挙上によって惹起される各種咀嚼筋の変化について はいまだほとんど明らかにされていない，また，咬合挙 上に際しての筋線維のタイプ別変化や，咀礵筋の組織変 化に関連した筋活動の変化などについても従来まったく 記载されていない.

広島大学歯学部歯科補緅学第 1 講座（指導：津留宏道教授） Department of Removable Prosthodontics, Hiroshima University, School of Dentistry (Director : Prof. Hiromichi Tsuru)

昭和 55 年 1 月 16 日受付
著者は, 臼歯部の咬合挙上に対する咀獣筋の組織反応 を明らかにする目的で, 成熟ラットに実験的に咬合挙上 を施し，それに伴う咀徱筋の組織学的変化を 6 部位につ いて経時的に検索するとともに，特に組織変化の強かっ た咀嚼筋については, 筋線維のタイプ別変化を主として 2 種類の酵素反応の消長を指標として組織化学的に検討 した. また,これらの変化に対応した筋活動についても 電気生理学的に検討を加えた.

\section{材料ならびに方法}

実験動物には 8 週䟥の Wistar 系雄性ラット総計 374 匹を用いた. 飼育には 固 型 飼料（オリエンタル醉母社 製， $\mathrm{M} \cdot \mathrm{F}$ 型）を用い，飼育条件は可及的に一定とし， 体重の変動は以下の各シリーズの各観察期間ごとに記録 した.

まず，組織学的変化を明らかにする目的で，200匹を， 咬合挙上を行うもの（実験群） 7 匹と対照群 3 匹の計 10 匹より成る 20 群に分け, 10 群については $1.0 \mathrm{~mm}$, 他 の 10 群については $2.0 \mathrm{~mm}$ の咬合举上を以下の方法に より実験群に施した. すなわち, sodium pentobarbital の腹腔内注射による麻酔下で, ラットの上䫑両側第 1 日 歯 (M1) にNo. 699 のフィッシャーバーを用いて深さ約 $2.0 \mathrm{~mm}$ のピン・ホールを平行に形成後印象 採得を行 い，作業用模型を作製した，次いで，パラレロメーター を利用して基準咬合平面を設定し，その模型上でパラタ ルバーにて連結した上頡 M 1 M 2 を被覆する高さ 1.0 および $2.0 \mathrm{~mm}$ の両側性咬合挙上装置を作製し，本装置 を実験群ラットに装着（図1）することによって左右臼 歯部での咬合を挙上した. なお，対照群では, 上顎 M1 にピン・ホールを形成し印象を採得するに留めた. 


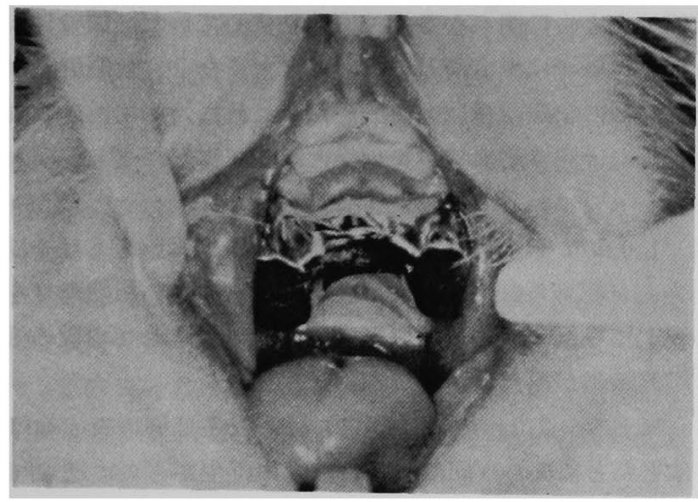

図 1 咬合挙上装置（高さ $2.0 \mathrm{~mm}$ ) を装着した口腔内 の状態

咬合挙上装置装着後 12 時間, $1,2,3,7,14,21$, $28 ， 42,84$ 日の各観察期間ごとに，1.0ならびに $2.0 \mathrm{~mm}$ 挙上の各 1 群を断頭し, 顔面皮膚を剝離した後，装置を 装着し下頭位を維持した状態で生理食塩水に浸したガー ゼに包み，室温下で 30 分間放置した. 次いで中性ホル マリンで 14 日間固定を行った後，Hiiemae ${ }^{15)}$ によるラ ットの咀緭筋の分類に従い, 咬筋浅層, 咬筋深層, 側頭 筋前腹, 側頭筋後腹, 内側翼突筋および外側翼突筋を採 取し, 通法に従って $6 \mu \mathrm{m}$ の横断およぴ縦断パラフィン 切片を作製し，ヘマトキリシン・エオジン (HE) 染色, マッソンのトリクローム染色 ${ }^{16)}$ および燐タングステン酸 ヘマトキシリン (PTAH) 染色 ${ }^{17)}$ 施し, 光顕的に観察 した.

次に，筋線維のタイプ別変化を検討する目的で, ラッ ト 160 匹を実験群 5 匹と対照群 3 匹の計 8 匹より成る 20 群に分け，10 群については $1.0 \mathrm{~mm}$ ，他の 10 群につい ては $2.0 \mathrm{~mm}$ の咬合挙上を前述の方法で行い, 以下の検 索を行った. すなわち, 前記の各観察期間ごとに 1.0 お よび $2.0 \mathrm{~mm}$ 挙上の各 1 群を断頭し，ただちに被検筋 (病理組織学的変化の最も強く認められた咬筋深層)を採 取し,ドライアイス・アセトンにて凍結の後, クリオス タットを用いて $-25^{\circ} \mathrm{C} て ゙ 12 〜 14 \mu \mathrm{m}$ の横断凍結切片を 作製し, 筋線維タイプの指標となる succinic dehydrogenase (SDH) 反応 ${ }^{18}$ および phosphorylase (PhR) 反応 ${ }^{19}$ の検出を行った. また，組織変化の注目された外 側翼突筋についても, ホルマリン固定後ゼラチンに包埋 し, 電子冷凍式ミクロトームにて 25 30 $\mu \mathrm{m}$ の横断切 片を作製し，やはり筋線維タイプの識別に利用されるズ ダンブラック $\mathrm{B}$ 染色 ${ }^{20)}$ を施し観察した.

さらに, 咀獣筋の組織変化と筋活動との関連を検討す る目的で, ラット 14 匹 (1.0および $2.0 \mathrm{~mm}$ 挙上群各 7
匹）を用い，咬合挙上装置装着の前後， $2 ， 7,28,84$ 日の各観察期間ごとに，無麻酔下における下顎安静位な らびに下顥両側切歯に $75 \mathrm{~g}$ の負荷をかけ等尺性収縮を 惹起させた場合の咬筋深層の筋活動を，ワイヤーエレク トロード（直径 $0.47 \mathrm{~mm}$ ) を用い極間距雄 $5.0 \mathrm{~mm}$ にて 双極誘導した．筋からの活動電位は増幅器 (三栄測器社 製，1206）で増幅してデータレコーダー(ソニーマグネ スケール社製，DFR-4515）に収録するとともに，電磁 オシログラフ（ビジグラフ，三栄測器社製，5L) を用い てペーパースピード 50 および $500 \mathrm{~mm} / \mathrm{sec}$ にてオシロ グラフペーパー上に描記した. 筋活動の分析は，等尺性 収縮時の単位時閒における筋活動量を累積積分計を用い て測定することにより行った.

\section{観 察 結 果}

\section{1. 咀嚼筋の組織学的変化}

12 時間後 : $2.0 \mathrm{~mm}$ 挙上群において，6種類の被検筋 のうち咬笳深層にのみ変化が見出された. 寸なわち, 同 部では筋組織の基本構築は対照群（図 2) と同様によく 保たれていたが，筋線維束間の間質に好中球，リンパ球 など少数の炎症細胞の浸潤を伴う軽度の充血, 水腫が認 められた (図 3 ).

$1.0 \mathrm{~mm}$ 挙上群では, いずれの被検筋にも変化を認め なかった.

1 日後 : $2.0 \mathrm{~mm}$ 挙上群の咬筋深層では, 炎症細胞浸 潤は筋線維束間のみならず，一部内筋周膜を越えて笳線 維束内にも認められ，一次束が水腫状に疎開するなど， 筋組織の構築に乱れを生じ始めていた，笳線維には混濁 腫脹や硝子様を呈するものも出現し，個々の笳線維の径 に大小不同を生じていた (図 4). また，咬筋浅層および 側頭筋前腹においても，筋線維束間に少数の炎症細胞が 浸潤していたが，筋組織の構築は比較的よく保たれてい た. 一方，側頭筋後腹，内側翼突筋，外側翼突筋にはほ とんど変化が認められなかった.

$1.0 \mathrm{~mm}$ 挙上群においても，咬筋の深層および浅層の 間質の一部に軽度の炎症が認められたが, 筋線維自体は 深層の一部でわずかに腫大を示す程度であった. その他 の咀嚼䇗には特に変化は見出されなかった。

2 日後 : $2.0 \mathrm{~mm}$ 挙上群の咬筋哚層においては, 笳組 織の構築の乱れがさらに強くなっていた. 炎症細胞は 1 日後よりも数を増して広範囲に分布し，しばしば筋線維 束内にも浸潤して筋線維の破壊と消失をきたしていた. 筋線維の径の大小不同はさらに著しくなり，径を減じ筋 
原線維が不明瞭となった変性線維が目立つとともに，円 形に腫大し硝子様を呈する筋線維が多数出現した（図 5).これらの変性線維では横紋は不明瞭となるか, あ るいは完全に消失していた（図 6 ）。また，変性線維の 付近には, 核小体の明瞭な胞状核を有する筋芽細胞様の 細胞がしばしば出現していた（図 7)、咬筋浅層にも同 様の変化が認められたが, 一般に笳線維の変性は軽度で あった. 一方, 側頭筇前腹および後腹や内側翼突筋では このような筋線維自体の変化はほとんど認められず, 間 質の一部に軽度ないし中等度の炎症性変化が認められる にすぎなかった．また，外側翼突筋では，対照群（図 8) に比して，エオジンに均一に濃染し多角形の縮小した横 断面を示す筋線維が多数発現し，これらはトリクローム 染色では特に強く赤染していた（図9）。これらの湌縮 した笳線維では横紋は大部分消失していたが, 筋䩗核に は変化が認められなかった（図 10).

$1.0 \mathrm{~mm}$ 挙上群では, 咬筋深層および浅層の間質にリ ンパ球を主とする軽度ないし中等度の細胞浸潤が認めら れ, これらは一部笳線維束内にも浸潤していたが, 筋線 維の径の大小不同は比較的軽度であり, 筋線維の硝子様 腫大も認められなかった (図 11). 一方, 側頭筋前腹お よび後腹や内側翼突筋には汪とんど変化はみられず, 外 側翼突筋においても $2.0 \mathrm{~mm}$ 挙上群にみられたような濃 縮した筋線維がごく少数認められるにすぎなかった.

3 日後 $: 2.0 \mathrm{~mm}$ 挙上群の咬筇染層においては, 炎症 所見が次第に筋の前方部に限局する傾向がうかがわれ (図 12), 残存する大小不同の筇線維間には胞状核を有し 筋芽細胞とみなされる細胞が多数分布していた (図 13). これらの細胞は互いに瘾合していわゅる“ myotube” を形成しながらその長さを増していた（図 14）. HE 染 色で好塩基性に染まる myotube の細胞質の中央には数 個の核が長軸に沿ってほぼ 1 列に配列しており, 粗に分 布する筋原線維にはいまだ横紋は認められなかった. ま た, 側頭筋前腹および内側翼突筋の炎症所見はほとんど 消失していた. 一方, 外側翼突筋における渃縮筋線維の 数は，2 日後よりもやや増加していた（図 15）.

$1.0 \mathrm{~mm}$ 挙上群においても, 咬筋深層および浅層の炎 症はそれぞれ 2 日後よりも軽減していた. 外側翼突筋に は濃縮笳線維が 2 日後と同程度に観察された.

7 日後: $2.0 \mathrm{~mm}$ 挙上群における咬笳深層の炎症細胞 はさらに減少し，核小体の明瞭な胞状核を有し細胞犋が 好塩基性に染まるところの再生管線維が多数認められた (図 16). これらの再生䈘線維の核はしばしば細胞質の 中央部に長軸と平行に 1 列に配列し, 筋原線維が密度を
増すとともに明らかな横紋構造を生じていた（図 17）. 咬筋浅層では炎症所見はほとんどなくなり, 対照群とほ ぼ同様の組織所見に復していた。これに対して，外側買 突筋には濃縮筋線維が 3 日後とほぼ同程度に認められ た.

$1.0 \mathrm{~mm}$ 挙上群では, 咬筋哚層の炎症細胞ももはやほ とんど認められず，対照群と区別のつかない組織所見を 呈していた.一方, 外側翼突筋には依然として少数の濃 縮笳線維が観察された。

14 日後 : $2.0 \mathrm{~mm}$ 挙上群における咬筋深層の炎症像は ほとんど消失し，同部での筋線維の再生がさらに進んで いた. 再生筋線維は, トリクローム染色では対照群に比 較してやや濃く染まっていたが，HE 染色では対照群 とほとんど変らない好酸性の染色性を回復していた. なお，再生筋線維の径は 7 日後に比べると増大していた が，対照群の状態にまでは復していなかった。核は 7 日 後と同様筋線維の中央に位置することが多かったが, 一 般にその大きさを減じて核小体が不明瞭になっていた (図 18，19). PTAH 染色標本においては横紋の形成が これらの再生筋線維に常に証明された（図 20). 一方, 外側翼突筋の所見は 7 日後とほぼ同様であった.

$1.0 \mathrm{~mm}$ 挙上群の組織所見は, 外側翼突筋を除くいず れの咀蹲筇においても対照群とまったく同様であった (図 21). 外側翼突筋には 7 日後と同様の変化が存続し ていた.

21 日後 : $2.0 \mathrm{~mm}$ 挙上群では, 咬筋哚層の炎症所見が 今や完全に消失し, 筇線維の再生がさらに進行してい た. 一方, 外側翼突筋には, $2.0,1.0 \mathrm{~mm}$ い゙れの举上 群においても,やはり濃縮した筋線維が 14 日後と同程 度に観察された.

28 日後 $: 2.0 \mathrm{~mm}$ 挙上群の咬筋深層においては, 筋の 基本構筑が完全に再建され, 再生筋線維と既存の筋線維 とをもはや識別し得なかった（図 22），筋線維の横紋は PTAH 染色によって常に明瞭に染め出された（図 23）. 一方, 外側翼突筋ではいずれの挙上群においても上記の 変化が相変らず存続していた.

42 日および 84 日後 : 外側翼突筋以外のすべての咀喂 筋が 2.0, $1.0 \mathrm{~mm}$ いずれの挙上群においても対照群と まったく同じ組織所見を呈していた（図 24，25）のに対 して, 外側翼突笳には依然として擞縮し横紋の消失した 等線維がこれまでと同程度に認められた（図 26，27）。

\section{2. 咬筋深層の組織化学的変化}

12 時間後 : $2.0,1.0 \mathrm{~mm}$ いずれの挙上群においても， 
対照群と同様の $\mathrm{SDH}$ 反応（図 28）ならびに $\mathrm{PhR}$ 反応 （図 29）が検出された. すなわち，SDH 反応ではホルマ ザン顆粒の强度あるいは中等度の規則的な沈着を示す筋 線維が多数を占め, 一方, PhR 反応では均一に強染され た笳線維と活性の弱い筋線維とがほぼ相半ばして見出さ れた.

1 日後 : $2.0 \mathrm{~mm}$ 挙上群では, $\mathrm{SDH}$ 活性を示す筋線 維の染色性が不均一に增強し，筋線維内におけるホルマ ザン顆粒の分布パターンが対照群に比べて不規則化して いた (図 30). また，PhR の活性には全般に著しい低下 が認められた (図 31).

$1.0 \mathrm{~mm}$ 挙上群では $\mathrm{SDH}$ 反応には変化がなかった が, PhR 活性は幾分低下していた.

2 日後 $: 2.0 \mathrm{~mm}$ 挙上群では, 径を減じあるいは破壊 された筋線維のSDH 反応による染色性が不規則となり， ホルマザン顆粒が部分的に強く凝集していた（図 32).

また, 円形に腫大し輪郭を保っている筋線維においては 染色性が不均一となり，ホルマザン顆粒が笳線維内に点 状に沈着していた．また，径を減じあるいは破壊をきた した筋線維では $\mathrm{PhR}$ の活性がほとんど消失していたが， 輪郭の保たれた筋線維は種々の程度の反応を回復してい た (図 33).

$1.0 \mathrm{~mm}$ 挙上群では, 径のやや小さい筋線維において $\mathrm{SDH}$ 活性がわずかに高まっていたのに対して, PhR 反 応は 1 日後とほぼ同様対照群よりもやや低下していた.

3 日後 $: 2.0 \mathrm{~mm}$ 挙上群では, 破壊された筋線維およ びその付近の筋芽細胞とみなされる細胞において SDH （図34）ならびに $\mathrm{PhR}$ (図 35) の活性がほとんど消失し ていた. 強いSDH 活性を示す筋線維内ではホルマザン 顆粒が部分的に強く凝集しており，筋鞘が不明瞭で箭線 維の変性をうかがわせたのに対して, 円形に腫大し弱い SDH 活性を示寸筋線維では, 筋鞘が明瞭でよくその輪 郭が保たれていた。輪郭の保たれた筋線維では，ホルマ ザン顆粒が周辺部では不規則に中心部では粗に沈着する 傾向があるほか，周辺部がコイル状に強染しいわゆる “ring fiber” と呼ばれる変化を示寸筋線維も一部に認 められた (図 36). 一方, これらの笳線維の $\mathrm{PhR}$ 活性は 比較的よく保たれていた（図37).

$1.0 \mathrm{~mm}$ 挙上群においては, 2 日後と同様の両酵素反 応が観察され, $\mathrm{SDH}$ 活性の軽度の上昇が一部の筋線維 に認められたのに対して, PhR 活性は対照群よりも幾分 低下していた.

7 日後: $2.0 \mathrm{~mm}$ 挙上群では, 輪郭のよく保たれた SDH 活性の低い觔線維に混しっって,かなり強いSDH 活
性を示す再生中の筋線維とみなされる細胞が多数認めら れた (図 38).これらの線維は径が小さく，一般に中心 部にホルマザン顆粒の不規則な点状凝集が認められた. また,これらの再生筋線維の $\mathrm{PhR}$ 反応も一般に不規則 であった（図39）。一方，輪郭のよく保たれた SDH 活 性の低、筋線維ではホルマザン顆粒の粗大化が認められ た（図 40）が, PhR 反応による均一な染色性は比較的よ く保たれていた（図 41).

$1.0 \mathrm{~mm}$ 挙上群ではいずれの醳素反応も対照群とほぼ 同程度に回復していた.

14 日後: $2.0 \mathrm{~mm}$ 挙上群では, 7 日後より径が大きく なった再生箭線維に扔いて，SDH 活性を示す範囲が筋 線維の中心部から周辺部人と拡大するとともに(図 42)， $\mathrm{PhR}$ の不規則な反応も次第に消失し, 対照群と同様の均 一な酵素活性を回復していた. 一方, 輪郭のよく保たれ た笳線維内では，7 日後にみられた SDH 反応による粗 大なホルマザン顆粒が消失の傾向を示し，また，均一な $\mathrm{PhR}$ 反応はよく保たれていた（図 43).

$1.0 \mathrm{~mm}$ 挙上群ではいずれの醳素反応も対照群とまっ たく同様であった.

28 日後: $2.0 \mathrm{~mm}$ 挙上群における再生筋線維の識別は もはや組織化学的にも困難であったが，一部の筋線維内 にはなおも SDH 活性の不規則な分布が認められた（図 44). $\mathrm{PhR}$ の反応所見は対照群とほぼ同様であった.

42 日および 84 日後: $2.0 \mathrm{~mm}$ 挙上群においても, 前 段階でみられた一部の筋線維の不規則な SDH 活性がい まや認められず (図 45), 両酵素反応による筋線維の染 色パターンは対照群とまったく同様に復していた（図 46, 47).

\section{3. 外側翼突筋の組織化学的変化}

$2.0 \mathrm{~mm}$ 挙上群で本筋にみられた特徵的な濃縮筋線維 は，ズダンブラックB染色によって濃青色を呈した（図 48).この変化は 2 日後以降 84 日後に至るまで常にほと んど同程度に認められた。

$1.0 \mathrm{~mm}$ 挙上群においても, 前群に比べ数は少ない が, 同様の形状と染色性を示寸笳線維が同じ観察期間中 常に同程度に存続していた (図 49).

\section{4. 咬筋深層の筋活動の変化}

$2.0,1.0 \mathrm{~mm}$ いすれれの挙上群においても，咬合挙上装 㯰装着前には下顎安静位での筋活動はほとんど認められ なかったが, 装置装着後より異常なスパイク様放電が記 録された (図 50).この筋放電は, $2.0 \mathrm{~mm}$ 挙上群では 


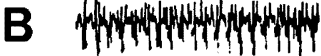

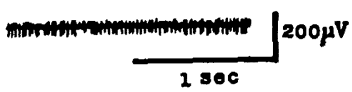

図 50 咬合举上装置装着前 (A) および直後 (B)の下額安 静位における咬筋深層の管活動

$2.0 \mathrm{~mm}, 1.0 \mathrm{~mm}$ いずれの挙上群において も, 装置装着直後に異常なスパイク様放電が認 められる.

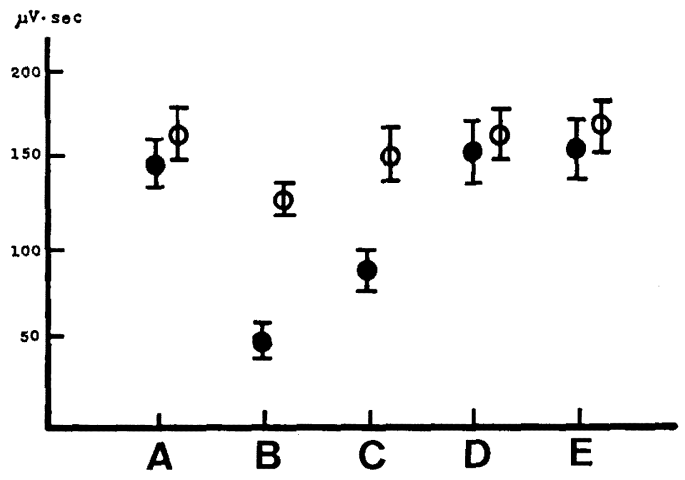

図 52 咬合举上に伴う咬筋深層の等尺性收縮時の筋活 動量の経時的変化

$2.0 \mathrm{~mm}$ (O印), $1.0 \mathrm{~mm}$ (O印) いずれの 挙上群においても，2 日後に隇少し，7 日後に は回復に向かっている。装置装着前 (A), 2 日 後 $(B), 7$ 日後 (C), 28 日後 (D), 84 日後 (E)

28 日後に，また $1.0 \mathrm{~mm}$ 挙上群では 7 日後にそれぞれ 消失した.

$2.0 \mathrm{~mm}$ 挙上群における等尺性収縮時の笳活動の観察 では， 2 日後に著明な振幅と棘波数の減少が認められ， その後は経時的に回復に向かい, 84 日後の筋活動は装置 装着前とほぼ同様に復していた（図 51). 一方, $1.0 \mathrm{~mm}$ 挙上群では, 2 日後にやや振幅が減少したが, 7 日後には 装置装着前の状態に復していた. また，等尺性収縮時の 䈘活動量は, $2.0 \mathrm{~mm}$ 挙上群で 2 日後に著明に減少して いたが，7日後には回復の傾向を示し，84 日後には装置 装着前とほぼ同様の値に戻っていた. 一方, $1.0 \mathrm{~mm}$ 挙 上群では，2 日後に筋活動量がやや減少したが，7日後 にはすでに装置装着前の值にまで回復していた(図 52).
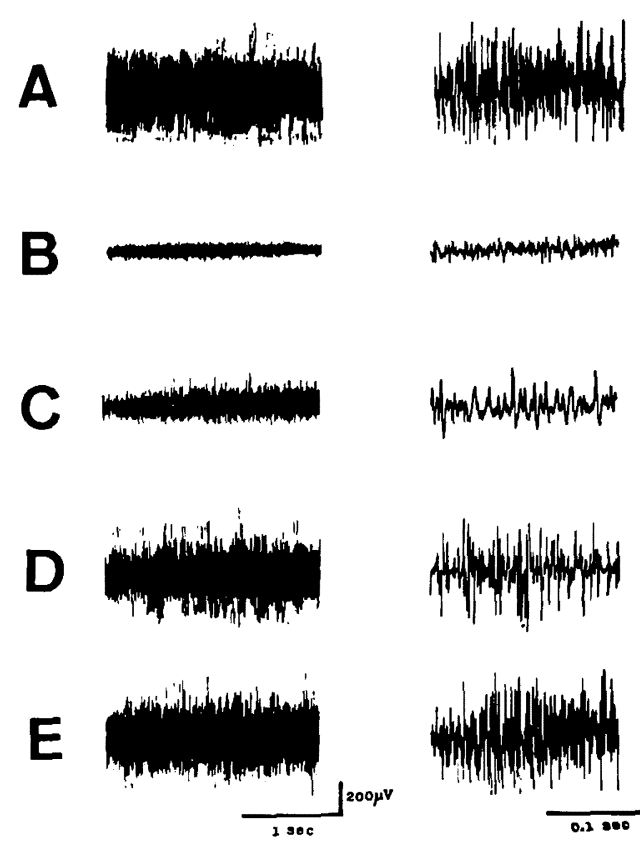

図 $512.0 \mathrm{~mm}$ 举上群の咬筋深層における等尺性収縮 時の筋活動の経時的変化

振幅と棘波数が 2 日後に著明に減少してい る. 装置装着前 (A), 2 日後 (B), 7 日後 (C), 28 日後 $(D), 84$ 日後 $(E)$
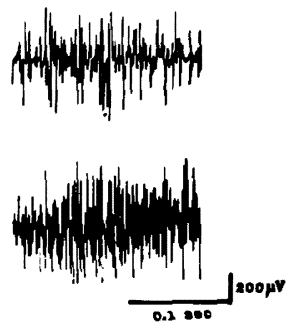

\section{考察}

\section{1. 実験方法について}

咬合挙上の実験的研究には, 従来, イヌ ${ }^{12)}$, ラット ${ }^{13)}$, およびサル14)を用いたものが報告されている.イヌの蝶 番運動のみによる咬合はヒトとは著しく異なる上に ${ }^{21,22)}$ 個体差が大きい欠点があり，また，サルについては，咬 合状態や咀嚼筋の構造がヒトと類似し比較的臨床に近い 方法で咬合挙上を行える利点がある反面，動物が特に高 価で入手にも困難な点があり，使用数にも制約を受けざ るを得ない.これに対して，ラットでは多数の動物に容 易に実験操作を加えることができ，しかも咀嚼筋の構造 や機能が解明されているので15,23 30), 本研究目的には比 較的適している.ラットの小さな口腔には精密な実験装 置の装着がはなはだ困難であるが31)，本研究では，individual tray を用いての印象採得により作製した作業用 模型をパラレロメーターに取り付け，技工操作を行うこ とによって, 観察期間中, 脱落や変形をきたすことな く, 一定の挙上量を確実に付与し得る精密な実験装置を 作製することができた. 
従来, 咬合挙上の実験は, 前菌部12 14) と臼歯部 $6,7,9)$ の それぞれについて試みられてきたが，臨床的な咬合挙上 は臼歯部で行われ，咀覆機能の面でも当然臼歯部が重視 されるので, 本研究では臼歯部での咬合挙上を採用し た. また, 咬合挙上は通常両側で行うこと, 加えて下颓 正中縫合部に可動性のあるラットでは片側性装置によっ て確実に咬合を挙上し得ない恐れがあったので，本研究 では両側性の挙上装置を用いた。

補緅臨床では一般に安静空隙が挙上量の目安とされて いるが ${ }^{10,11)}$, 時には安静空隙の範囲を越えた挙上の行わ れることもある21. ラットに扔いてもヒトと同様下影安 静位が存在し24,27), その安静空陌は臼歯部で約 $1.0 \mathrm{~mm}$ とされている27)。そこで著者は，ラット 20 匹を用いて， $1.0,2.0,3.0 \mathrm{~mm}$ の 3 種類の挙上量を設定した予備実 験を行い 28 日間観察したところ, $3.0 \mathrm{~mm}$ 挙上群では著 明な体重減少をきたし，多数のラットが死亡したので, 本研究に用いる挙上量はラット臼歯部の安静空隙に相当 する 1.0 およびその倍量である $2.0 \mathrm{~mm}$ の 2 種類に決定 した. なお, $2.0 \mathrm{~mm}$ の挙上量はラットにとって過大と も思われたが，2 日後までは体重の減少がみられたもの の 7 日後以降は対照群とほぼ同様の体重増加を示したこ とから，一応適応可能範囲にあると考えた.

筋組織はあらゆる刺激に対して収縮で応答するため, 被検筋を断頭後即座に固定すると収縮したまま固定され てしまい, 所見を誤って解釈する可能性があり ${ }^{32}$ ，その ため, 筋生検体を直接筋に触れる “ no touch technique" が推奖されている33). そこで, 本研究の組織 標 本 の作成に当っても，近藤 ${ }^{34)}$ の方法に準して筋の收縮を減 じた後, 頭部全体を固定液に浸漬することによって, 筋 に人工的侵襲を加えることなく固定を遂行した. 一方， 組織化学的検索に当っては未固定の新鮮凍結切片を作成 することが望ましいので ${ }^{35)}$ ，咬筋深層は採取後迅速に凍 結したが，外側翼突筋については，その解剖学的位置か ら未固定で取り出すことが技術的に困難であるため，木 ルマリン固定後凍結切片を作成し, SDH 活性とよく一 致し筋線維のタイプ別分類の指標に利用され得るズダン ブラックB染色を適用した ${ }^{36)}$ ．なお，得られた組織変化 が実験操作, 特にピン・ホール形成時の露髄による筋へ の細菌感染の波及や，実験時の開口による筋の変化など による可能性を検討するため，対照群においても装置装 着前までの過程を実験群と同様行行ったところ, 組織変 化がまったく認められなかったので, 本研究で得られた 咀緭筋の組織変化は, 咬合挙上によるものとみなしてよ かろう.
設定した咬合挙上の状態は，歯の咬耗，挺出あるいは 圧下などによって変動する恐れがある. そこで，観察期 間中の咬合状態の推移を別群のラットを用いてシリコ

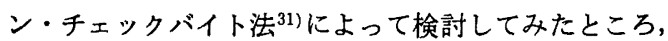
$2.0,1.0 \mathrm{~mm}$ いずれの挙上群でも全観察期間を通じて光 の透過性にはほとんど変化がなく, M 3 部に咬合接触の ないことが明らかであった．固形食で飼育したラットの 歯は咬耗することが知られているが37)，本研究では 4 歯 にわたる挙上装置によって咬合力が分散される上に，装 置が対合歯の咬合面全体に接触するためか，対合歯の咬 耗ないし磨耗はきわめて少なかった．また，下頡 $M 3$ に 挺出の認められなかったことは，挙上装置が上顎 M1 M2 の咬合面を被覆しており, 下顎 M3 が咀嚼時には上 䫑 M1 M2 と, 下䫑安静位でも上䫑 M2 と対合するこ と ${ }^{24)}$ によると解せられる. 次に, 装置自体の磨耗につい ても，咬合接触部にわずかに光沢を示す小面が認められ る程度であったことから，無視して差仕えなかろう．す なわち, 付与した挙上の条件は観察期間を通じて維持さ れていたことが明らかである.

\section{2. 咀噮筋の組織学的変化について}

筋の炎症は傷害に対する生体の直接の防禦反応である だけでなく，惹起された組織障害に対する二次的現象で もある ${ }^{38)}$. 本研究で観察された咀㘉筋の最初の組織変化 は, 咬合挙上により咀翾筋が強制的に伸展されたことに よると考えられる急性炎症の所見 (12 時間 2 日後)で あり, その伸展の過度な咬筋（特に深層）では筋線維の 変性を随伴していた.

一般に, 笳の病理組織学的変化は筋原性および神経原 性の変化に大別され, 神経原性変化では小径線維が束状 あるいは集合性に出現する以外, 筋組織の構筑の保存さ れるのが特徴とされている ${ }^{34,39}$. 本研究では笳線維の変 性を伴う炎症性の破壊ならびに修復など, もっぱら筋原 性とみなされる組織変化が得られ，筋線維の伸展に基う く myopathy を表わすものと解釈された.

変性に陥った筋線維は, 肉芽組織によって置換される ことなく，筋線維自体の再生による治湑過程を辿った. 高度に分化した細胞の再生は困難とされ, 従来の認識で は, 骨格筋細胞もこのような permanent cell の範疇に 含められてきた ${ }^{40)}$. しかしながら, 最近の実験的研究に よると，骨格筋の再生は限られた範囲内で可能であ $\eta^{41 \sim 47)}$ むしろ stable cell として扱われる傾向にあ $\Xi^{48)}$. 従来, 骨格筋の再生様式に関しては連続説 ${ }^{41)}$ と非 連続説 ${ }^{42)}$ とが論議され，一般に myopathy に際してみら 
れる再生にはこれらの両様式が共存するといわれてい る ${ }^{39)}$ ，本研究においても，変性筋線維の一端に直接して 筋芽細胞が認められるとともに，筋変性部に広範囲にわ たって筋芽細胞が出現するなど，両再生様式が識別され た.

炎症性の破壊ないし変性から再生へ至る一連の組織変 化はもっぱら咬筋と側頭笳に認められ，咬筋哚層で特に 強く，次いで咬筋浅層，側頭筋前腹の順に強かった. ラ ットの各咀畄筋と咀嚼運動との関連はよく知られてお $\eta^{21,23,24,27,30)}$, 下䇗を举上する管は咬筋深層, 側頭筋前 腹および内側翼突筋であるといわれている23,24,27,30).こ れらの下䝷挙上に関与する筋は咬合举上によって伸展さ れ, その伸展度の強弱によって惹起される組織変化に差 異を生じたものと推察される. 特に, 咬筋深層は咀罚機 能の主役を演じる臼歯部に作用する筋であり ${ }^{24)}$, 咬合挙 上によって最も強く伸展されたためとりわけ強い変化を きたしたものと考えられる. また, 咬筋浅層は, ラット の咀嚼運動に特有の incisive stroke と power stroke の間の前方運動を制御する筋であり $23,24,30)$, 挙上装置に よって下顎が後下方に回転された結果伸展されて, 同し 傾向の組織変化をきたしたものと考えられる. これに対 して，下顎举上筋でありながら内側翼突筋に変化がほと んど認められなかったのは，その停止部が臼歯部後方の 下顎枝内面に存在するためあまり強く伸展されなかった こと，筋重量および垂直べクトルが咬筋深層のそれぞれ 1/4 と $1 / 3$ であること ${ }^{23,24)}$, さらには本筋が側方運動に も関与すること淿などの諸要因に基うくくものと推察され る. また, 側頭筋後腹にほとんど変化が認められなかっ たのは，本筋が下顎を後退させる機能を有するもの $の^{23,24,30)}$ ，その作用範囲が小さいため，咬合挙上による 伸展がほとんどなかったためであろう.

外側翼突箭では, 上記の組織変化とはまったく異なっ た炎症を伴わない筋線維の濃縮が注目され，変性萎縮を 表わすものと推定された. このような変性萎 縮につい ては, 本研究の場合, 特に神経原性, 圧迫性あるいは廃 用性などの機構によること ${ }^{40}$ が考えられる. 神経原性の 筋萎縮, ことに末梢神経の傷害時には, 初期より種々の 程度の萎縮筋線維の出現することが知られており ${ }^{49)}$, 本 実験においても，咬合挙上によって関節頭の位置が変化 することによって本筋の停止部付近の末梢神経が傷害さ れた可能性があるし，あるいは，過度の開口により本筋 の停止部が関節頭によって圧迫され50), いわゆる圧追性 萎縮を生じた可能性も否定できない，また，本筋の走行 と咬合挙上による関節頭の前下方への位置変化とを考え
併せると，咬合举上によって本筋が弛緩される可能性も 強いので,この点からは廃用性萎縮とみなすのがむしろ 妥当なようにも思われる. 本研究からは以上のいずれの 機構によるものかは確定し得ないが，以すれれせよ本筋 の萎縮性変化に関節頭の変位が重要な因子であることは 疑いがないように思われる.

本研究では，2.0, $1.0 \mathrm{~mm}$ 挙上群のいずれにおいて む，外側翼突筋を除くすべての咀嚼筋が咬台挙上に順応 することが明らかであった。 これは呾緭筋組織の順応の 困難性を指摘した従来の見解 ${ }^{12 ~ 14)}$ とは相違した成 績で あるが，順応をきたした因子としては，実験動物，挙上 方法および挙上量などの違いを考える必要があろう．本 研究で用いたのは 8 週龄ラットであり，同じ種類の動物 では若いほど䇨の順応を起こしやすいとすれば14)，同じ くラットを用いた北村 ${ }^{13)}$ の実験結果との相違は年齗差に 帰せられよう。また, 前歯部で挙上を行った先人の方法 では12 14)， 臼歯部に咬合接触がないために咀嚼筋の筋活 動が障害されて, 本研究とは異種の組織変化が惹起され たものと推察される. ラットの前歯部における $1.5 \sim 2.0$ $\mathrm{mm}$ の挙上量は ${ }^{13)}$, 前歯, 臼歯および関節頭の位置関係 から臼歯部での $1.0 \mathrm{~mm}$ 程度に相当すると考えられ,こ の量的な差も実験結果の相違に関係するであろう.

咀嚼筋が咬合举上後の新しい下顎位に順応するのは, 急激な伸展によって変性消失をきたした筋線維が，その 後相次いで再生し, 新しい筋の長さを獾得することによ ると考えられる. 特に, 笳付着部は咬合挙上に対して活 発に反応することが注目されており ${ }^{14)}$ ，本研究です咬筋 深層の付着部付近の再生䈘線維が長さを増しながら付着 部方向一伸展する所見が得られた.これに対して，外側 翼突筋には84 日後に至ってもなお 回復の所見が認めら れなかったことから，関節頭の位置が咬合举上の予後に とってきわめて重要と考えられ, 補緅臨床における咬合 挙上に当っては, 関節頭の位置を変えない hinge axis を中心とした後方限界運動路上での举上を行うべきこと が強く示唆された.

挙上量の相違によって組織変化には明らかな差異が認 められ, $2.0 \mathrm{~mm}$ 挙上群により強い変化が認められた. 河邨 $5^{51)}$ は，筋の人為的伸展は筋原長の $10 \%$ 以内に 留 めるべきであると述べているのに対して，桜井 ${ }^{52}$ は漸次 伸展する場合には $17 \%$ まで伸展できると主張している．

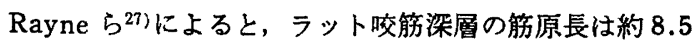
$\mathrm{mm}$ であり, $2.0 \mathrm{~mm}$ の挙上量 (約 23\% の伸展に相当) は一見許容範囲を越えるように思われるが, 安静空隙が 存在することから実際の伸展量はもっと少ないと考えら 
れ，肉芽性修復をきたさなかった本研究結果からみても， この量は伸展し適応し得る籁囲内にあったといえよう.

従来, 安静空隙を基準として咬合举上量を設定した実 験はまったく見当らず，その点臨床に近い条件で得られ た本研究結果は, 補緅臨床に重要な指標を与えると考え られる. すなわち, 安静空隙に相当する $1.0 \mathrm{~mm} の$ 挙上 に対して, 外側翼突筋以外の咀霞筋では一過性かつ可逆 性の軽度の炎症が実験開始初期にみられたのみであった ことは，前述のごとく関節頭の位置を変えない限りは， 咬合挙上の基準に安静空隙を利用してこの範囲内での挙 上を行うことが妥当なことを示している. これに対し て, 安静空隙の範囲を越える $2.0 \mathrm{~mm}$ の挙上では, 最終 的に咀徱筋に順応が認められたとはいえ，筋線維の強い 変性や炎症性破壊を生じていたので, ラットほど笳再生 力も強くないであろうヒトにおいては，肉芽による修 復, すなわち咀嚼筋の瘏痕化をきたす可能性もあるの で, その咬合挙上に当っては長期にわたり段階的に行う などの慎重な態度が必要であろう.

\section{3. 咬合挙上に伴う咀噮筋の筋線維タイプ別変化につ いて}

哺乳類の骨格筋は赤筋, 白筋および中閒筋の各筋線維 タイプから構成され, 赤筋線維は酸化酢素, 解糖酵素の いずれにも強い活性を，白筋線維は解糖酵素に強、活性 を,また中間筋線維は酸化酵素にかなりの活性を示すこ とが知られている ${ }^{53,54)} .2 .0 \mathrm{~mm}$ 挙上群の咬筋深層にお いては，酸化醏素である SDH の強度ないし中等度の活 性が証明された多数の筋線維が変性消失から再生に至る 過程を示すように思われ，解糖酵素である $\mathrm{PhR}$ 活性む その過程によく対応した消長を示した. これに対して, $\mathrm{SDH}$ 活性の弱い少数の筇線維では観察期間中よくその 輪郭が保たれ, $\mathrm{PhR}$ 活性も比較的強く保たれていた. これらの所見から, 本研究においては主として赤筋およ び中間筋線維が変性ないし消失と再生の過程を辿り, 白 筋線維にはほとんど組織変化を生じなかったものと推定 される. 一般に, 骨格筋の表層部には白筋線維が多数分 布し，深部ほど赤筋線維が多くなる傾向があるのに対し て, 中間筋線維は一様に分布するとされている ${ }^{55,56)}$.ラッ 卜咀籓筋における各筋線維タイプの分布についてはいく つかの報告があるが57 59)，咬筋深層での各筋線維タイプ の分布状況についてはいまだ十分検討されていない，そ こで著者は, 対照群の咬筋深層のこれら 2 種類の醳素反 応を施した標本において，500本の箭線維を無作為に選 んで検討したところ，この部が赤筋線維 $14 \%$ ，白筋線
維 19\% および中間筋線維 $67 \%$ より成るという結果を得 た.この観察結果からも，咬筋深層では赤筋および中間 筋線維が傷害を被り, 輪郭を保っていた少数の筋線維が 白筋線維であるとみなすことは妥当と思われる.

本研究において，筋線維タイプによって異なった組織 変化の認められたのは, 各タイプの代謝様式や機能の相 違に基づくように思われる. 因に, 赤筋線維は高い好気 性および嫌気性代謝を行う fast-twitchoxidative glycolytic fiber であり, 中間筋線維は好気性代謝の優勢な slow-twitch-oxidative fiber である ${ }^{53,54)}$. 咬合挙上を 行ったラットでは, 新たな下顎位を維持する必要から咀 罚筋のトーヌスの高まることが推察され，そのため姿勢 制御を司る tonic な性質を有する中間筋線維60) に強い変 化がみられたものと考えられる. また，持続的な等尺性 収縮を行って新たな下䪽位を維持するためには，高い酸 化能と血液供給が要求されるが61), これらが相対的に不 足し, そのため赤筋や中間筋線維の代謝に変化を生じた とも推察される. これに対して, 大部分の白箭線維に変 化の認められなかったことは, 本筋線維が kinetic な運 動機能を司ること ${ }^{53,54)}$ に基うくものであろう.

咬合举上後, 咬筋深層の赤筋および白筋線維には PhR 活性の消失あるいは低下が認められた. 筋肉の PhRに は活性型 $\mathrm{a}$ と不活性型 $\mathrm{b}$ が存在し, b から a への変換に は PhR b kinase が必要であり,この䤃素活性には cyclic AMP の関与することが知られている62). 本研究 で用いた $\mathrm{PhR}$ 反応の基質反応液には補酵素として $5^{\prime}$ AMP しか添加されていないため19), $\mathrm{PhR}$ b は証明さ れず, したがって本研究で検出された $\mathrm{PhR}$ 活性は活性 型 $\mathrm{a}$ を示すと考えられる. 活性型 $\mathrm{a}$ に変化がみられたの は, 筋か収縮を繰り返すと PhR a が b に変化するこ と ${ }^{63)}$ ，また筋が傷害されるとエネルギー生産系が嫌気性

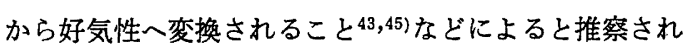
る. 同時期の SDH 活性が筋線維内で不規則な分布を示 したのも，またエネルギー生産系の好気性への変換に関 連するように思われる.

$\mathrm{SDH}$ 活性はミトコンドリアの局在に一致し64)，筋線 維の再生が進むにつれてミトコンドリアの数と容積が筋 線維の中心部から周辺部一と次第に増加し, これに対応 して SDH 活性の増强することが報告されている46). 本 研究でみられた再生筇線維の SDH 活性もこの所見によ く一致しており，再生時の赤筋掞よび中間筋線維のミト コンドリアに同様の変化が生じていることがうかがわれ る.

Susheela ら ${ }^{45}$ おょよび Reznik ら ${ }^{46)}$ は，病理組織学的な 
らびに組織化学的な両面から筋組織の再生を検索し, 組 織化学的にみた再生完了の時期が, 染色性の異常は一部 の筋線維にみられるものの, 実質的には病理組織学的に みた再生完了の時期と一致すると報告している. 本研究 においても, 組織学的に咬筋深層の再生が完了したと考 えられる 28 日後の標本の一部に SDH 活性の強い筋線維 がなおもみられたので, 再生は 28 日後から 42 日後の間 に完了したと考えられる.

筋線維タイプと神経支配の間には密接な関連があ $\eta^{65)}$, 再生過程における各タイプの筋線維の分化は新し い神経支配のもとになされることが指摘されてい る45,46). 本研究においても, 再生が完了したとみなされ る時期には対照群と同様の各筋線維タイプの分布状況が 認められたところから，すでに神経支配が再確立してい たと考えられ，このことは後述の筋活動の所見ともよく 一致した.

$1.0 \mathrm{~mm}$ 挙上群の咬筋樑層の赤筋あるいは中間筋線維 にも初期に SDH 活性の上昇がみられたことについては, 筋の規則的な持続運動に好気性エネルギー生産系の増加 が必要とされること泊，あるいは前述した筋エネルギー 系の変換などに基づくことが推察される. この変化は 7 日後にはもはや認められなかったので, 本筋の順応はこ の時期までに完了したと解釈されるが，咬合挙上を安静 空隙の範囲内で行う場合にも筋の初期反応には一応注目 する必要のあることを示唆する所見である.

ラットの外側翼突筋はほとんど赤筋および白筋線維で 構成されることが知られ59), また, 本研究の対照群にも 中間筋線維を識別できなかったことから，ズダンブラッ ク Bに濃染した萎縮筋線維は赤笳線維とみなされる. ズ ダン色素に染色性を有するのはミトコンドリアのリン脂 質や貯蔵脂質と考えられるので67), 萎縮赤筋線維がこの ように濃染したのはミトコンドリア内の脂質の変化に基 うく可能性がある.

\section{4. 咬筋深層の形態的ならびに機能的変化の関連につ いて}

筋組織に炎症や変性をきたすと, 筋電図干涉波形にお ける筋活動電位の振幅が減少することが知られてお $\eta^{49,68)}$, 四肢末梢筋の生検と筋電図との関連が神経筋疾 患の診断面で注目されている. しかしながら, 咀嚼筋の 組織変化と機能変化とを実験的に結びつけた報告はいま だ見当たらず, その点, 咬合挙上に伴う咀嚼筋の組織変 化と機能との関連を明らかにすることはきわめて有意義 と考えられる.
等尺性収縮を惹起させるための負荷の重量決 定に当 り, 種々の負荷量を用いた予備実験を行ったところ, 約 $75 \mathrm{~g}$ を変曲点として, これよりも重い場合は閉口筋が抵 抗できなくなり，軽い場合は下頭の開閉動作が頻繁にな って等尺性収縮を起こさないことが判明したので，本研 究では $75 \mathrm{~g}$ の負荷を採用した.

本研究で認められた下顎安静位に括ける挙上直後の異 常なスパイク様放電は, Schwartz ${ }^{69)}$ が急激な咬合の変 化や筋の伸展により咀嚼筋の spasm が惹起されること を指摘しているように，筋の spasm の存在を示唆して いる.このスパイク様放電は, $2.0 \mathrm{~mm}$ 挙上群では 28 日 後に, また $1.0 \mathrm{~mm}$ 挙上群では 7 日後に至って消失した ところから，それぞれの時期にラットは新しい下顎位に 順応したことが明らかであり，同時期における組織変化 ともよく対応する.

$2.0 \mathrm{~mm}$ 挙上群における等尺性収縮時の筋活動量は, 2 日後に著明に減少した.この時期は, 筋線維の変性が 組織学的に最も著明であった時期に相当するので, この 筋活動量の減少は筋活動に参加する神経筋単位 (NMU) の減少に基づくことが推測される.この時期の標本で は, 組織変化を示さない笳線維も同時に認められたが, 下䅡安静位に㧍ける筋電図所見からこれらの筋 線 維に spasm が起こり疲労をきたしていることが示唆され る $^{70)}$. 一般に, 筋が疲労した時, 疲労前と同し張力を発 生させるためにはより多くの NMU の動員ないしインパ ルスの頻度の増加を必要とし71), その結果筋活動量も増 大する. したがって，この時期にも挙上前と同一の負荷 をかけることによって同一張力を発生したことからは筋 活動量がむしろ増大したと考えねばならないが，実際に は筋活動量は著明に減少していた. Scherrer ら ${ }^{72)} の$, 主働筋の疲労時にはその協働筋が活動に参加するとの考 えに従えば，本実験においても下䫑挙上の主働筋である 咬筋深層の協働筋である側頭筋前腹および内側翼突 笳 ${ }^{23,30)}$ の䈘活動が元進することによって, 咬筇深層の張 力の減少を補償していたと考えられるので, 笳活動量が 减少した事実は必ずしも先人の見解 ${ }^{70,71)}$ と矛盾しない. また, この時期の側頭笳前腹や内側翼突筋に強い変性像 がみられなかったことも，この考えを支持するものであ る.

さらに, 筋線維の再生の進行に伴って筋活動量が増加 したことからも, 本研究によって咀嚼筋の形態的変化が その機能によく対応することが確認されたといえよう. 


\section{総括}

成熟ラットの上顎両側臼歯部に 2 種類の高さ（安静空 隙を基準とした $1.0 \mathrm{~mm}$ およびその倍量である $2.0 \mathrm{~mm}$ ) の咬合挙上装置を装着することによって実験的に咬合を 挙上し, 咬筋浅層, 咬笳深層, 側頭筋前腹, 側頭筋後腹, 内側翼突筋, 外側翼突筋の組織学的変化を経時的に観察 するとともに，組織変化の特に注目された咬筋哚層と外 側翼突筋については，酸化および解糖酵素反応あるいは 脂肪染色所見の消長を指標として筋線維のタイプ別変化 を組織化学的に検索し, 併せて組織変化に対応した筋活 動についても電気生理学的に検討を加え, 下記の結果を 得た.

1. $2.0 \mathrm{~mm}$ 挙上群の咬筋ならびに側頭筋において, 笳線維の変性を伴う炎症性破壊と筋線維の再生による治 瘾過程が, 12 時間後より 42 日後にかけて観察された. この一連の組織変化は咬筋深層で最も強く, 次いで咬筋 浅層, 側頭筋前腹の順に強く認められた. これに対し て, 側頭筋後腹および内側翼突筋では， 2 日後に軽度の 炎症所見が得られた以外はほとんど組織変化が認められ なかった. このような各咀嚼笳の変化の差異は, 咬合挙 上による各筋の伸展度の強弱に基うくしのと推察され た. 一方, 外側翼突筋では, 炎症を伴わない筋線維の変 性萎縮が 2 日後より観察され，84 日に至ってもなお存続 したところから, 咬合挙上の予後にとって本筋の停止部 である関節頭の変位が重要であることが示唆された.

2. $2.0 \mathrm{~mm}$ 挙上群の咬筋深層では, その主成分であ る赤筋および中間筋線維が変性と再生による治瘱過程を 辿るのに対して, 少数を占める白筋線維にはほとんど組 織学的変化がないものと推定された. また，外側翼突筋 に特徵的にみられた萎縮筋線維は赤筋線維であると推定 された。

3. 等尺性収縮を行わせた $2.0 \mathrm{~mm}$ 挙上群の咬筋深層 の筋活動は，その組織変化によく対応して変動し，咀嚼 筋の組織変化と機能との密接な関連性が確認された.

4. $1.0 \mathrm{~mm}$ 挙上群においても, やはり赤筋あるいは 中間筋線維に $2.0 \mathrm{~mm}$ 挙上群と同様の組織化学的消長が 注目されたが，一般にその変化は軽度であった. 病理組 織学的にも筋線維の変性は見出されず，咬筋深層および 浅層に一過性の炎症が惹起されていただけで，側頭筋前 腹にも組織変化は認められず, 臨床において安静空隙の 範囲内で咬合挙上を行うことの妥当性が示唆された. 以上の成績より, 実験的な咬合挙上に対するラット咀
嚼筋の反応部位と反応様式，特に赤筋および中間筋線維

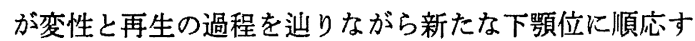
ることが, 筋活動との対応のもとに明らかとなり, 補経 臨床における咬合挙上のあり方に有意義な示唆を与える ことができた.

本論文の要旨は, 昭和 53 年 9 月の第 28 回広島大学歯学会例 会, 昭和 53 年 11 月の第 65 回日本補緅歯科学会 (大阪) および昭 和 54 年 2 月の第 30 回広島大学歯学会例会において発表した.

稿を終わるに臨み, 終始ご愁篤なるご指導, ご校閲を賜わりま した本学歯科補経学第 1 講座津留宏道教授に深甚なる感謝の意 を表します。

本研究遂行にあたり, 終始病理学的立場から適切なこ教示と ご校閲を賜わりました本学口腔病理学講座二階宏昌教授ならび に生理学的立場から種々のご教示とご校閲を賜わりました本学 口腔生理学講座菅野義信教授に束心より感謝致します。

また, 研究遂行における本学歯科補緅学第 1 講座長沢亭助教 授ならびに佐藤隆志講師をはじめ教室員各位のご協力に感謝致 します.

\section{文献}

1) Goodkind, R. J. : Mandibular movement with changes in the vertical dimension, J. Prosthet. Dent., 18: 438 $\sim 448,1967$.

2）石原莳郎，井上昌幸，河野正司，川口豊造，坂東永一， 丸山雅昭, 小沢 実, 真柳昭紘, 中尾勝彦:オーラル・ リハビリテーションの1症例に拈ける下䫇位の診断, 補 緅誌, $13: 204 \sim 211,1969$.

3）玉川博, 佐々木元, 長沢 烹, 津留宏道: Enamel Hypoplasia を伴亏患者の補緅的処置の一症例, 広大粚 誌, $9: 90 \sim 97,1977$.

4）監 稔, 古屋良一, 塩沢育己, 矢作光昭：咬合位の低 下により生じた䫇機能異常の1症例, 補緅誌, 22： $460 \sim 468,1978$.

5）坂本正朔：補綴学領域における下䫟の垂直的ならびに 水平的变位に関する筋電図学的研究, 九州歯会誌, 23 : 544 572, 1969.

6) Christensen, J.: Effect of occlusion-raising procedures on the chewing system, Dent. Practit., $20: 233$ $\sim 238,1970$.

7) Drechsler, F., Kohno, S., Kühl, W. und Neuhauser, B.: Neurophysiologische Analyse der Wirkungen okkusaler Interferenzen auf Regulation und Koordination der kaumuskulatur, Dtsh. Zahnärztl. Z., 28: 695 704, 1973.

8) Tryde, G., McMillan, D. R., Stoltze, K., Morimoto, 
$80-216$

T., Spanner, O. and Brill, N.: Factors influencing the determination of the occlusal vertical dimension by means of a screw jack, J. Oral Rehabil., $1: 233 \sim 244$, 1974.

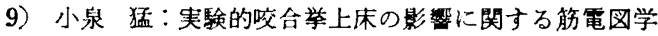
的研究，歯科医学，38：267 288，1975.

10）森本俊文, 河村洋二郎, 松代浩明：咬合举上に対する Screw jack 法の適用と下䫇の位置感覚, 基礎誌, 18 : 53 59, 1976.

11）山崎達夫, 佐々木元, 高木道弘, 棟久信宏, 佐藤隆志, 津留宏道: 咬台挙上に括沙る Mandibular Kinesiograph の応用，広大幽誌，10：281 285，1978.

12）花岡 宏：咬台举上時の閉口筋の順応性についての実 験的研究，九州歯会誌，25:71 85, 1971.

13）北村隆信：咬台挙上後の咀謝笳の順応性に関する病理 組織学的研究, 九州歯会誌, $27: 409 \sim 420,1974$.

14）车田龍生：罘間距離增大後の成猿および若猿にお汁る 組織順応性に関する実鈳的研究，九州雪会誌，28： 559 581, 1975.

15) Hiiemae, K. and Houston, W.J.B.: The structure and function of the jaw muscles in the rat (Rattus norvegicus L.) I. Their anatomy and internal architecture, Zool. F. Linn. Soc., 50 : 75 99, 1971.

16) Masson, P. J.: Some histological methods. Trichrome staining and their preliminary technique, $\mathrm{J}$. Tech. Methods, $12: 75 \sim 90,1929$.

17) Lillie, R.D.: Histopathologic technic and practical histochemistry, 537 538, McGRAW-HILL BOOK COMPANY Inc., New York, 1965.

18) Nachlas, M.M., Tsou, K., Souza, E. D., Cheng, C. and Seligman, A. M.: Cytochemical demonstration of succinic dehydrogenase by the use of a new p-nitropheny! substituted ditetrazole, J. Histochem. Cytochem., 5; 420 436, 1957.

19.) Takeuchi, T.: Histochemical demonstration of phosphorylase, J. Histochem. Cytochem., 4 : 84, 1956.

20）岡本耕造, 上田政雄, 前田隆英, 水谷昭：顕镫鏡的組織 化学, 338 339, 医学書院, 東京, 1965 .

21) Schumacher, G. H.(窪田金次郎訳)：各種動物の咀嚼型

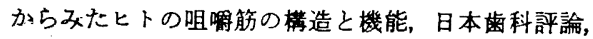
$394: 127 \sim 132,1975$.

22）上條雍彦：口腔解剖学 2 胆学, 付 2 , アナトーム社, 東 京, 1966.

23) Hiiemäe, K. M.: Masticatory function in the mammals, J. Dent. Res., 46, suppl. 5 : 883 893, 1967.

24) Hiiemäe, K. M. and Ardran, G. M. : A cineflurographic study of mandibular movement during feeding in the rat (Rattus norvegicus), J. Zool. Lond.;
$154: 139 \sim 154,1968$.

25) O'dell, N. L., Todd, G. L. III and Barnard, G. R. : Musculskeletal arrangements for lateral mandibular movements in the rabbit and rat, Electromyographic and other analyses, J. Dent. Res., 49: 1111 1117, 1970.

26) Nordstrom, S.H. and Yemm, R.: Sarcomere length in the masseter muscle of the rat, Archs. oral Biol., $19: 895 \sim 902,1972$.

27) Rayne, J. and Crawford, G. N.C.: The relationship between fibre length, muscle excursion and jaw movements in the rat, Archs. oral Biol., $17: 859 \sim 872$, 1972.

28) Risnes, S.: Mandibular movement capacity in the rat, Scand. J. dent. Res., 81 : 170 173, 1973.

29) Weijs, W. A. : Morphology of the muscles of mastication in the albino rat, Rattus norvegicus (Berkenhout, 1769), Acta Morphol. Neerl-Scand., 11: 321 $\sim 340,1973$.

30) Hiiemae, K.: The structure and function of the jaw muscles in the rat (Rattus norvegicus L.) III. The mechanics of the muscles, Zool. F. Linn. Soc., $50: 111$ $\sim 132,1971$.

31）高木勇藏：外傷性咬合による齿の支持組織の変化に関 する実験的研究，広大㙁誌，10：70～88，1978.

32）佐野 豊: 組織学研究法, 325 328, 南山堂, 東京, 1968.

33) Appendix $B$ to the minutes of the meeting of the research group on neuromuscular diseases, held in Montreal, Canada, on 21 September, 1967 : Report of a subcommittee on quantitation of muscle biopsy findings, J. neurol. Sci., $6: 179 \sim 188,1968$.

34）近藤喜代太郎：施生娭体の組織学的観察, 日本臨休, $27: 13 \sim 24,1969$.

35）武内忠男, 清水信夫, 小川和朗：酵素組織化学, 27 28, 朝倉書店, 東京, 1969.

36) Ogata, T.: A Histochemical study of the red and white muscle fibers Part I: Activity of the succinoxydase system in muscle fibers, Acta Med. Okayama $12: 216 \sim 227,1958$.

37) Stahl, S.S. and Dreizen, S.: The adaptation of the rat periodontium to prolonged feeding of pelet, powder and liquid diets, J. Periodontol., $35: 312 \sim 319$, 1964.

38）宇尾野公義, 木下真男：筋病理アトラス，26〜39, 医学 書院, 東京, 1972.

39）高橋和郎：筋肉病学, 278 294, 南江堂, 東京, 1976 .

40）緒方知三郎：病理学入門, 73〜294; 南山堂, 東京, 1967.

41) Gay, A.J. and Hunt, T.E.: Reuniting of skeletal 
muscle fibers after transection, Anat. Rec., 120:853 $\sim 871,1954$.

42) Lash, J. W., Holtzer, H. and Swift, H. : Regeneration of mature skeletal muscle, Anat. Rec., $128: 679 \sim 697$, 1957.

43) Smith, B.: Histochemical changes in muscle necrosis and regeneration, J. Path. Bact., 89 : 139 143, 1965.

44) Reznik, M. and Hansen, C. J. L.: Mitochondria in degenerating and regenerating skeletal muscle, Arch. Path., $87: 601 \sim 608,1969$.

45) Susheela, A.K., Hudgson, P. and Walton, J. N. : Histological and histochemical studies of experimentally-induced degeneration and regeneration in normal and dystrophic mouse muscle, J. neurol. Sci., 9 : 423 442, 1969.

46) Reznik, M. and Engel, W. K.: Ultrastructual and histochemical correlations of experimental muscle regeneration, J. neurol. Sci., 11: 167 185, 1970.

47) Hall-Craggs, E. C. B. : Ischemic muscle as a model of regeneration, Exp. Neurol., $60: 393 \sim 399,1978$.

48) Robbins, S. L. : Pathologic basis of disease, 55 105, W. B. Saunders Co., Philadelphia, 1974.

49）高橋和郎：神経・筋疾患の診断法とその問題点，日本臨 休, $27 ： 82 \sim 88,1969$.

50) Vaughan, H.C.: Discussion of "mandibular joint disease of kinesiopathic origin", J. Prosthet. Dent., 16 : 329 337, 1966.

51）河邨文一郎, 細野㘿：下肢延長術, 整形外科, 17 ： $872 \sim 881,1966$.

52）桜井 喬：下肢延長術の実験的研究（筋長一筋力曲線の 検討を中心として)，東京慈恵会医誌，40：378～393, 1966.

53) Edgerton, V.R. and Simpson, D. R.: The intermediate muscle fiber of rats and guinea pigs, J. Histochem. Cytochem., $17: 828 \sim 838,1969$.

54) Peter, J. B., Barnard, R. J., Edgerton, V. R., Gillespie, C. A. and Stempel, K. E. : Metabolic profiles of three fiber types of skeletal muscle in guinea pigs and rabbits, Biochem., $11: 2627 \sim 2633,1972$.

55) Gordon, G. and Holbourn, A. H.S. : The mechanical activity of single motor units in reflex contractions of skeletal muscle, J. Physiol., 110:26 35, 1949.

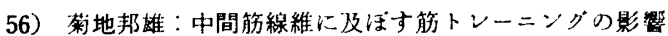
に関する組織学的研究，体力科学，22：17〜25, 1973.

57) Hiiemae, K.: The structure and function of the jaw muscles in the rat (Rattus norvegicus L.) II. Their fiber type and composition, Zool. F. Linn. Soc., 50: 101 109, 1971.

58) Tsukamoto, S. and Mori, M. : Distribution of muscle fibers of three types differentiated by succinic dehydrogenase activity in the skeletal muscle, Arch. histol. jap., $26:$ 329 339, 1966.

59) Hiraiwa, T.: Histochemical properties of masticatory muscles of growing rat and of matured mammals, Comp. Biochem. Physiol., 59A : 231 238, 1978.

60）永井寅男：筋の生理学, 181～208, 朝称書店, 東京, 1974.

61) Ianuzzo, C. D., Gollnick, P. D. and Armstrong, R. B. : Compensatory adaptations of skeletal muscle fiber types to a long-term functional overload, Life Sciences, 19 : 1517 1524, 1976.

62）奥田九一郎：生化学の基礎, 75〜78, 南江堂, 東京, 1970 .

63）岸野泰雄：新組織化学, 317 345, 朝合書店, 東京, 1977.

64) 牧田登之, 小川和朗：病態醘素組織化学, $13 \sim 18$, 朝倉 書店, 東京, 1972.

65) Dubowitz, V.: Cross-innervated mammalian skeletal muscles. Histochemical, physiological and biochemical observations, J. Physiol., 193 : 481 496, 1967.

66) Holloszy, J. O. : Biochemical adaptations in muscle, J. Biol. Chem., 242: 2278 2282, 1967.

67）近藤正美：骨格筋の機能分化と構造との相関性に関す る組織学的研究, 第 1 編: 骨格筋線維の機能分化々構造 との相関性に関する研究, 岡山医学誌, $71: 3569 \sim 3580$, 1959.

68) Brusa, A., Loeb, C., Moretti, G. and Sacco, G. : A comparison of histologic and electromyographic findings in various neuromuscular disorders, Neurol., $13: 630 \sim 640,1963$.

69) Schwartz, L.(河村洋二郎訳)：䯪関節異常, 3 94, 医 歯薬出版，東京， 1962.

70) Laskin, D. M.: Etiology of the pain-dysfunction syndrome, J. A. D. A., 79 : 147 153, 1969.

71) Kadefors, R., Kaiser, E. and Petersen, I.: Dynamic spectrum analysis of myo-potentials and with special reference to muscle fatigue, Electromyography, $8: 39$ $\sim 74,1968$.

72) Scherrer, J.et Monod, H.: Le travail musculaire local et la fatigue chez I'homme, J. de Physiol. (Paris) $52:$ 419 501, 1960. 


\section{付図説明}

図 2 対照群ラットの咬筋深層, HE×100.

図 3 咬笳深層 (2.0 mm 挙上群，12 時間後)：間質に軽度の 炎症細胞浸潤が認められる. $\mathrm{HE} \times 100$.

図 4 咬箭深層 $(2.0 \mathrm{~mm}$ 举上群, 1 日後)：筋線維束内にも 細胞浸潤があり，箭線維径に大小不同を生じている.トリ クローム $\times 100$.

図 5 咬筋深層 $(2.0 \mathrm{~mm}$ 举上群，2 日後）：炎症細胞が広籁 囲に浸潤し，筋線維の変性消失が著しい. H E×100.

図 6 咬筋深層 (2.0 mm 挙上群, 2 日後)：筋線 維の横紋が しばしば消失している. PTAH $\times 100$.

図 7 咬筇深層 $(2.0 \mathrm{~mm}$ 挙上群, 2 日後)：筋線 維の消失部 に筋芽細胞様の細胞（矢印）が出現している.トリクロー $\Delta \times 100$.

図 8 対照群ラットの外側翼突筋. トリクローム $\times 400$.

図 9 外側翼突筋 $(2.0 \mathrm{~mm}$ 举上群, 2 日後): 赤色に強染し た萎縮筋線維が多数認められる. トリクローム $\times 400$.

図 10 外側㳯突筋 $(2.0 \mathrm{~mm}$ 挙上群, 2 日後)：萎縮筋線 維で は横紋が消失している．トリクローム $\times 400$.

図 11 咬笳深層 (1.0 mm 举上群, 2 日後)：間質に少数の炎 症細胞が認められるが，筋線維に異常はみられない。 $\mathrm{HE} \times 100$.

図 12 咬筋深層 $(2.0 \mathrm{~mm}$ 举上群, 3 日後)：炎症は脇の前方 部に限局している.トリクローム $\times 100$.

図 13 咬筋深層 $(2.0 \mathrm{~mm}$ 挙上群, 3 日後): 残存する筋線維 間に䈘芽細胞が多数認められる. $\mathrm{HE} \times 400$.

図 14 咬筋深層 $(2.0 \mathrm{~mm}$ 举上群, 3 日後)：筋芽細胞は互い に療合して“ myotube” (M) を形成している. PTAH $\times 400$.

図 15 外側巽乫筋 $(2.0 \mathrm{~mm}$ 举上群, 3 日後) : 萎縮筋線維が 強く赤染している. トリクローム $\times 100$.

図 16 咬筋梁層 $(2.0 \mathrm{~mm}$ 举上群, 7 日後) : 核小体の明瞭な 胞状核を有する再生箭線維が多数認められる. $\mathrm{HE} \times 400$.

図 17 咬筋深層 (2.0 mm 挙上群, 7 日後): 再生筋線維では 核が中央部に 1 列に配列し，明らかな横紋が形成されてい る. $\mathrm{PTAH} \times 100$.

図 18 咬筋深層 $(2.0 \mathrm{~mm}$ 举上群, 14 日後): 再生筋線維の核 は胞体の中央部に位置している. $\mathrm{HE} \times 400$.

図 19 咬笳深層 (2.0 mm 挙上群，14日後)：再生筋線維の細 長くなった核では核小体が不明膫である(矢印)。

$\mathrm{HE} \times 400$.

図 20 咬筋深層 (2.0 mm 举上群, 14 日後)：再生笳線維に横 紋が明瞙に認められる. PTAH $\times 400$.

図 21 咬管深層 $(1.0 \mathrm{~mm}$ 举上群, 14 日後): 対照群とほほ同 栐の筋組織が認められる. H E $\times 100$.

図 22 咬筋深層 $(2.0 \mathrm{~mm}$ 举上群, 28 日後): 筋組織の基本權 築が完全に再建されている，H E×100.

図 23 咬筋深層 $(2.0 \mathrm{~mm}$ 举上群, 28 日後): 筋線維の横紋は きわめて明瞭である. PTAH $\times 400$.

図 24,25 咬㙝深層 (2.0 mm 举上群, 42 日後および 84 日後)：
いずれの所見も対照群とまったく同様である.

トリクロームおよび H E $\times 100$.

図 26, 27 外側翼突管 $(2.0 \mathrm{~mm}$ 举上群, 42 日後および 84 日 後)：いずれにも，荌縮し横紋の消失した㬳線維が存続し ている. トリクロームおよび PTAH $\times 100$.

図 28 対照群ラット咬笳深層の SDH 反応：ホルマザン顆粒の 規則的な沈着を示寸能線維が多数認められる. $\times 100$.

図 29 対照群ラット咬笳深層の $\mathrm{PhR}$ 反応：均一に強染寸る筋 線維と活性の低い筋線維とが相半ばして認められる。 $\times 100$.

図 30 咬筋深層の SDH (2.0 mm 举上群, 1 日後): 活性を示 寸筋線維の染色性が不均一に增強している， $\times 100 ．$

図 31 咬筋深層の $\mathrm{PhR}$ (2.0 mm 举上群, 1 日後):すべての 筋線維に活性の著しい低下が認められる。 ×100。

図 32 咬筋深層のSDH (2.0 mm 举上群，2 日後)：変性や破 壊に陥った箭線維の活性が不規則になっている. $\times 100$.

図 33 咬㳙深層の $\mathrm{PhR}(2.0 \mathrm{~mm}$ 举上群, 2 日後): 変性队破 壊に陥った筋線維の反忘は消失しているが, 円形に腫大し た筋線維は種々の活性を示している。 $\times 100$.

図 34，35 咬筋深層の SDH および PhR $(2.0 \mathrm{~mm}$ 举上群、 3 日後)：筋線維の破壊部ではいずれの醳素活性もほとんど 消失している. いずれも×100.

図 36 咬䇨深層の SDH (2.0 mm 举上群, 3 日後) : 種々の活 性を示す筋線維ではホルマザン顆粒が不規則に沈着してお り，いわゆる“ ring fiber”（矢印）と呼ばれる変化も認 められる. $\times 400$.

図 37 咬筋深層の $\mathrm{PhR}(2.0 \mathrm{~mm}$ 举上群, 3 日後) : 円形に腫 大した筋線維の活性は比較的よく保たれている， $\times 400$.

図 38 咬筋深層のSDH $(2.0 \mathrm{~mm}$ 挙上群, 7 日後): 再生能線 維とみなされる細胞（矢印）は中心部に不規則な活性を示 している. $\times 100$.

図 39 咬筋深層の PhR (2.0 mm 举上群, 7 日後)：再生筋線 維に不規則な活性が認められる。 $\times 100$.

図 40 咬筋深層の SDH $(2.0 \mathrm{~mm}$ 挙上群， 7 日後)：輪郭の上 く保たれた活性の低い筋線維ではホルマザン顆粒の粗大化 が認められる。 $\times 400$.

図 41 咬筋深層の PhR (2.0 mm 挙上群, 7 日後): 再生筋線 維の活性は不規則であるが，輪郭の保たれている筋線維で は活性が比較的強く保たれている，×400.

図 42 咬筋深層のSDH (2.0 mm 举上群, 14 日後): 再生筋線 維の周辺にも強い活性が認められる。 $\times 100 。$

図 43 咬筋深層の PhR (2.0 mm 举上群, 14 日後): 再生筋線 維の不規則な PhR 活性が消失している. $\times 100$.

図 44 咬筋深層の SDH (2.0 mm 挙上群, 28 日後): 再生筋線 維の反応をもはや識別できない, $\times 100$.

図 45 咬筋深層の SDH $(2.0 \mathrm{~mm}$ 挙上群, 42 日後): 不規則な 活性を示す筋線維は認められない． $\times 100$.

図 46，47 咬管哚層の SDH および $\mathrm{PhR}(2.0 \mathrm{~mm}$ 举上群, 84 日後：いずれも，筋線維に対照群とまったく同様の反応 パターンが認められる、いずれも×100.

図 48 外側翼突筋のズダンブラック B $(2.0 \mathrm{~mm}$ 举上群, 2 日 後)：萎縮筋線維は濃青色に染まっている。 $\times 100$.

図 49 外側翼笑妫のズダンブラック B $(2.0 \mathrm{~mm}$ 举上群. 84 日 後). 青色に強染した萎縮筋線維が依然として認められる。 $\times 100$. 


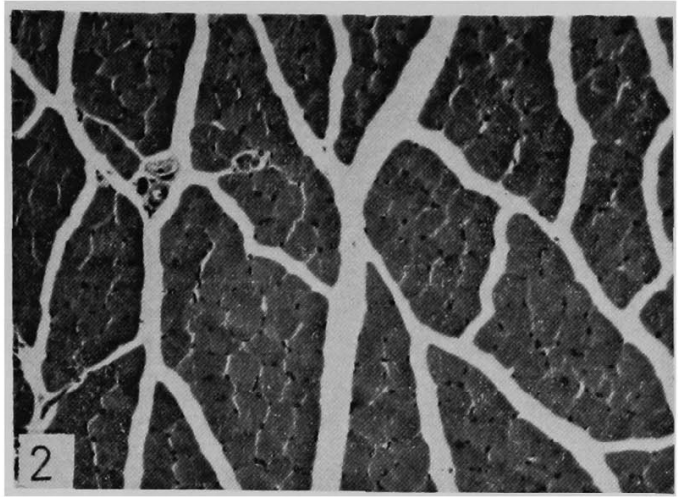

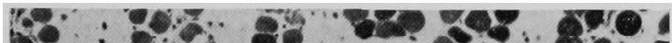

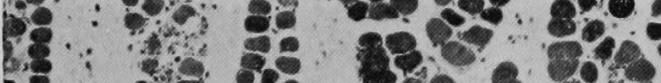

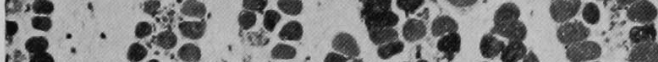

Li:

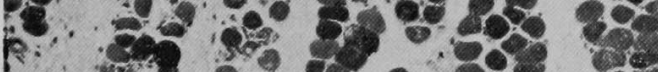
i. vis b.

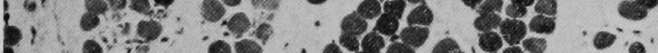

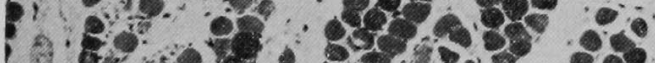

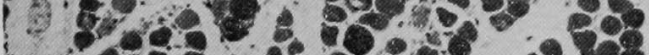
i: 14 tom: 20\%
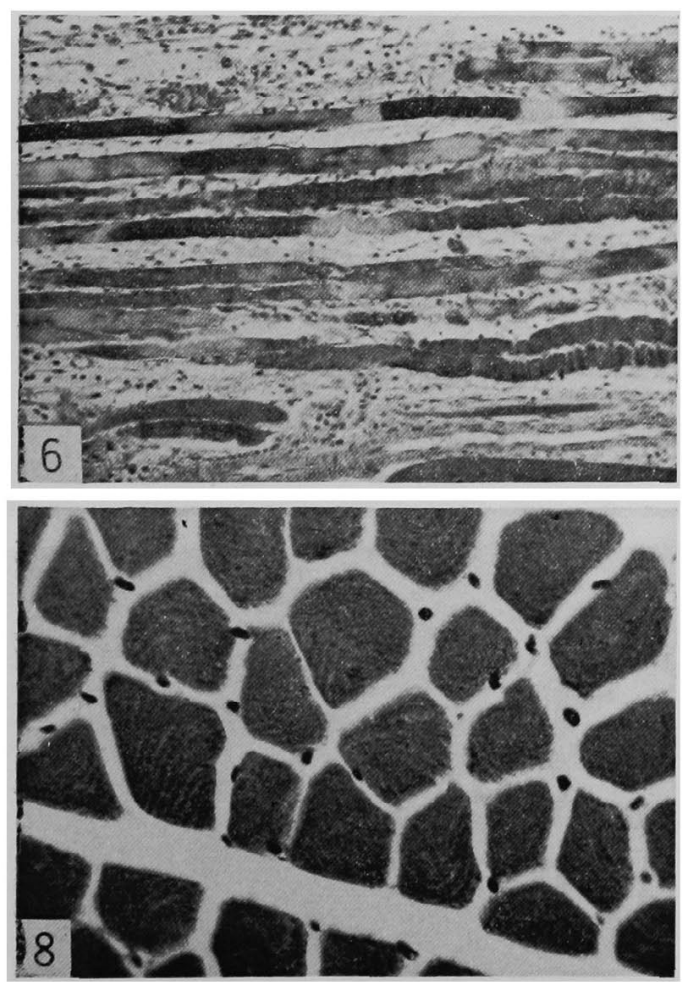

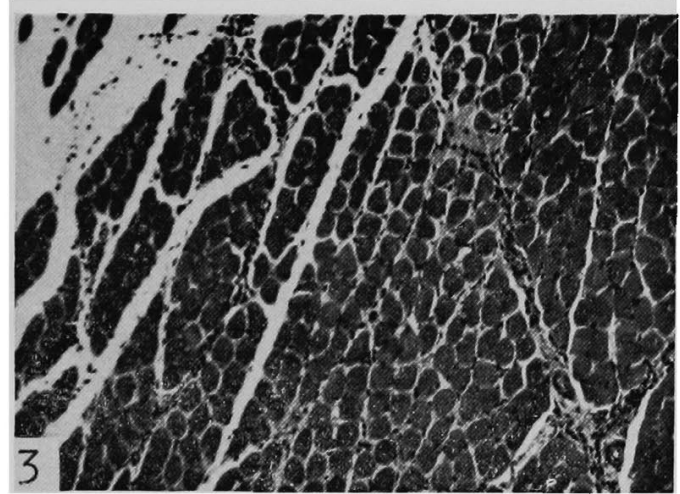
1.

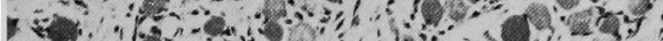
id i.

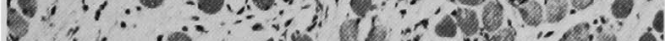

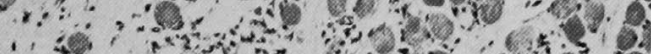

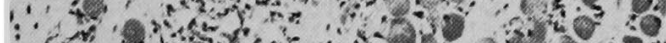
.6. 3n

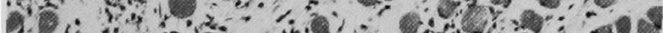

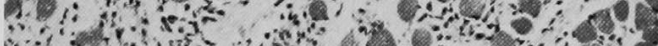

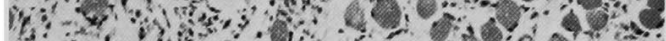

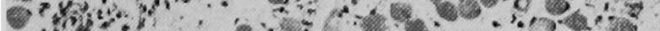

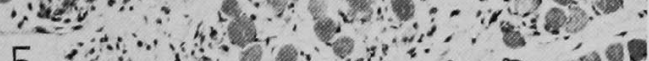

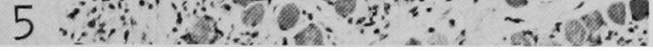
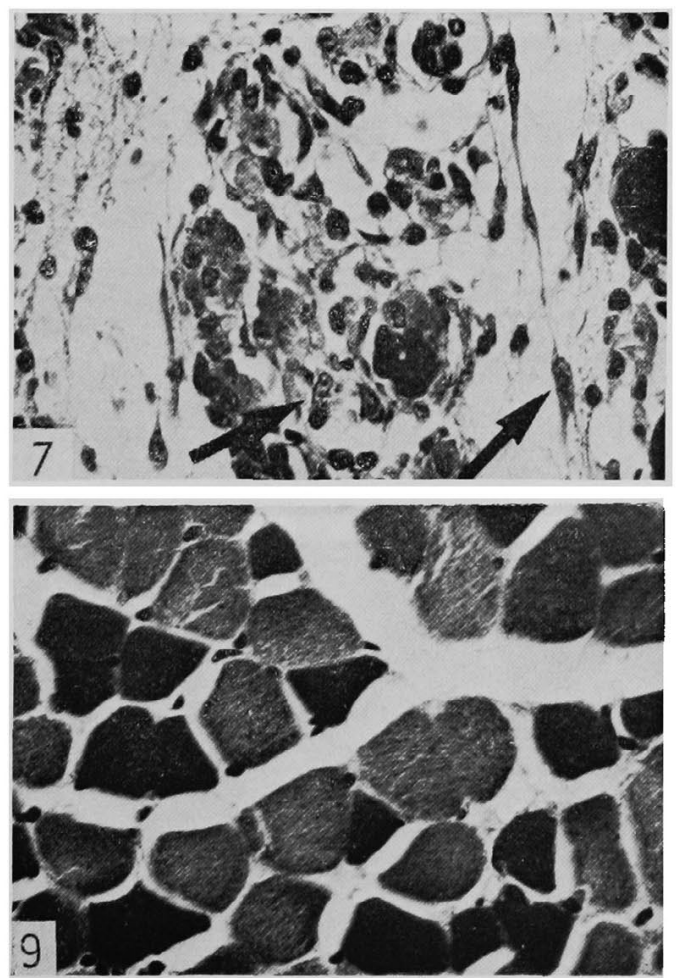


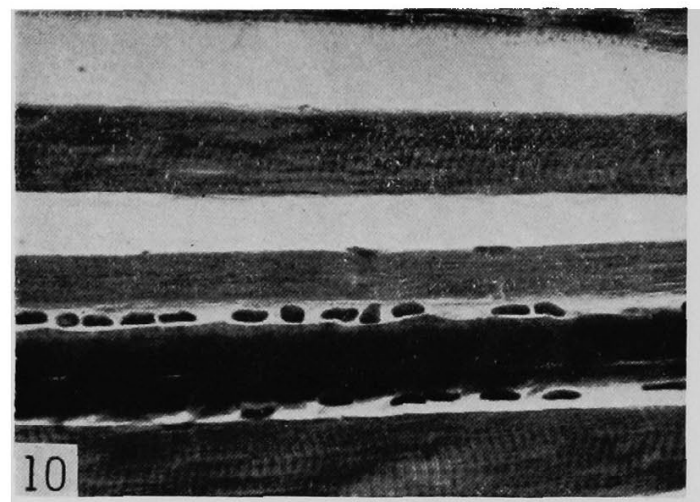

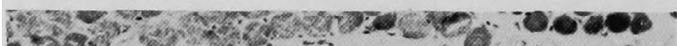

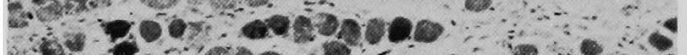

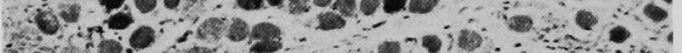

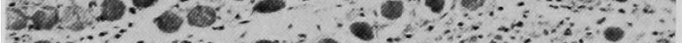
3)

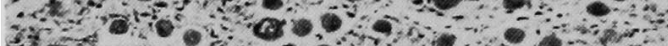

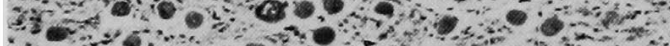

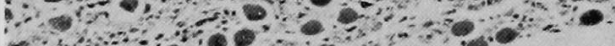
ary a

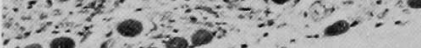

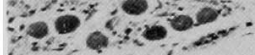

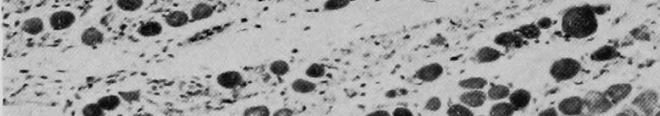

$1250 \%$ of
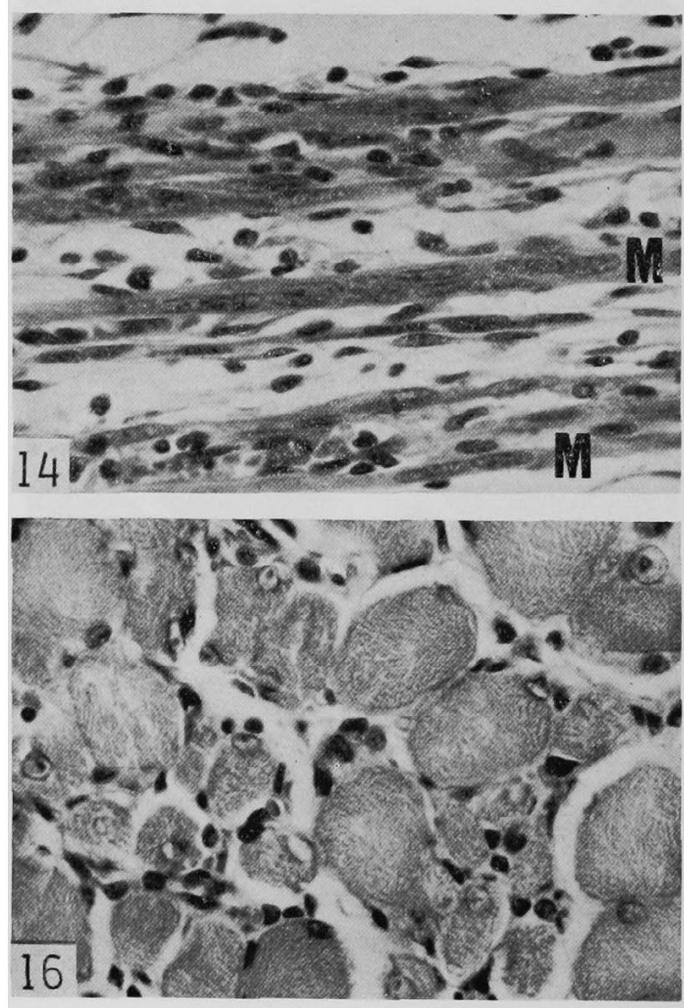

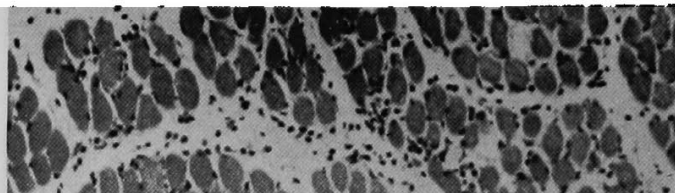

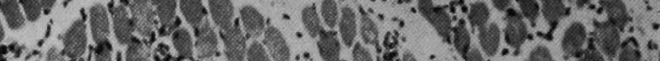

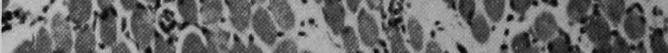

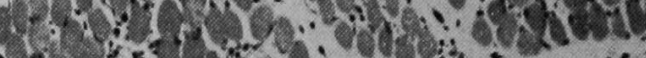

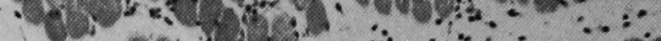

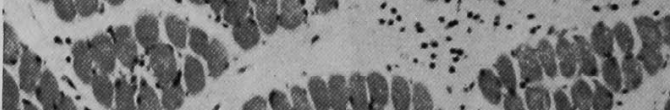

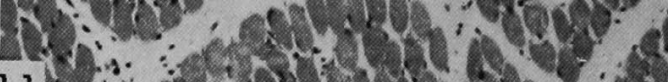

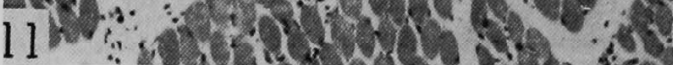

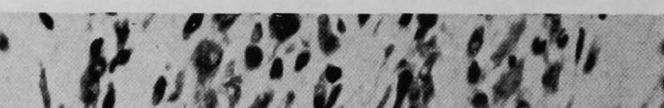

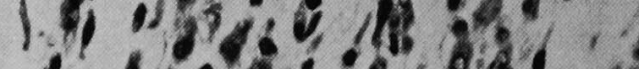

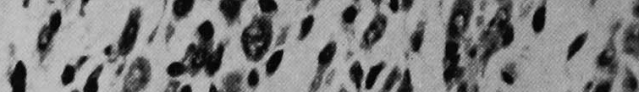

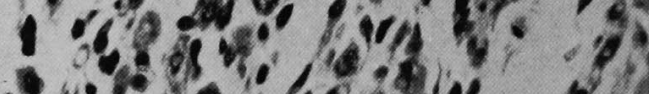

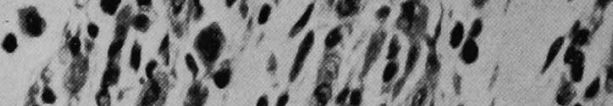

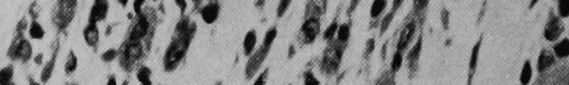

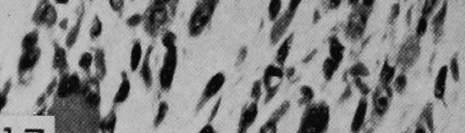

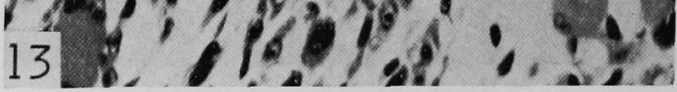
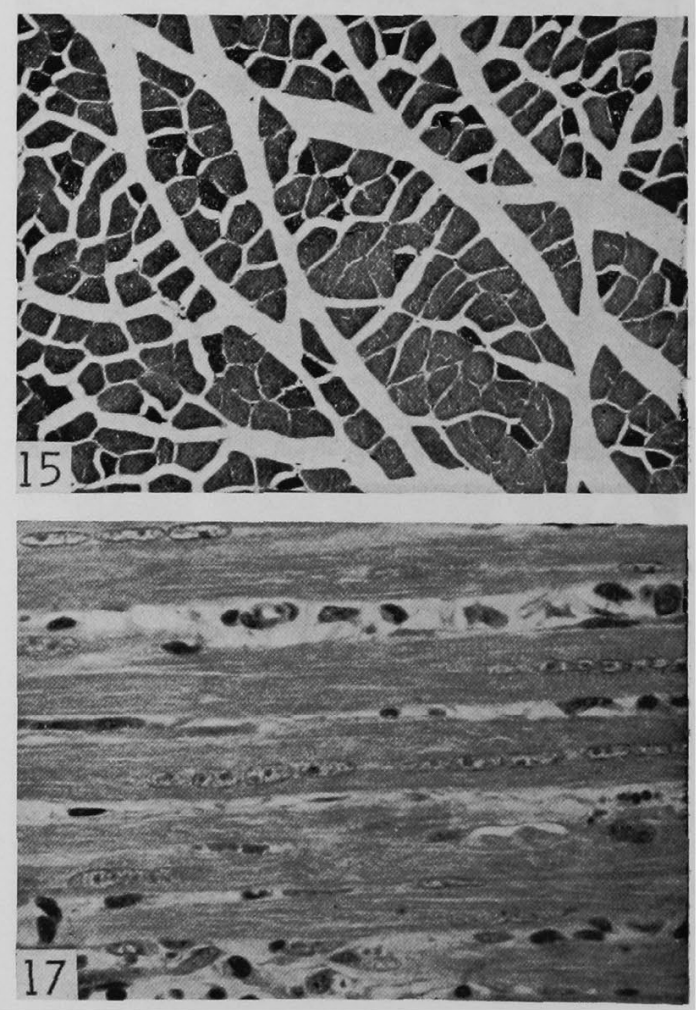

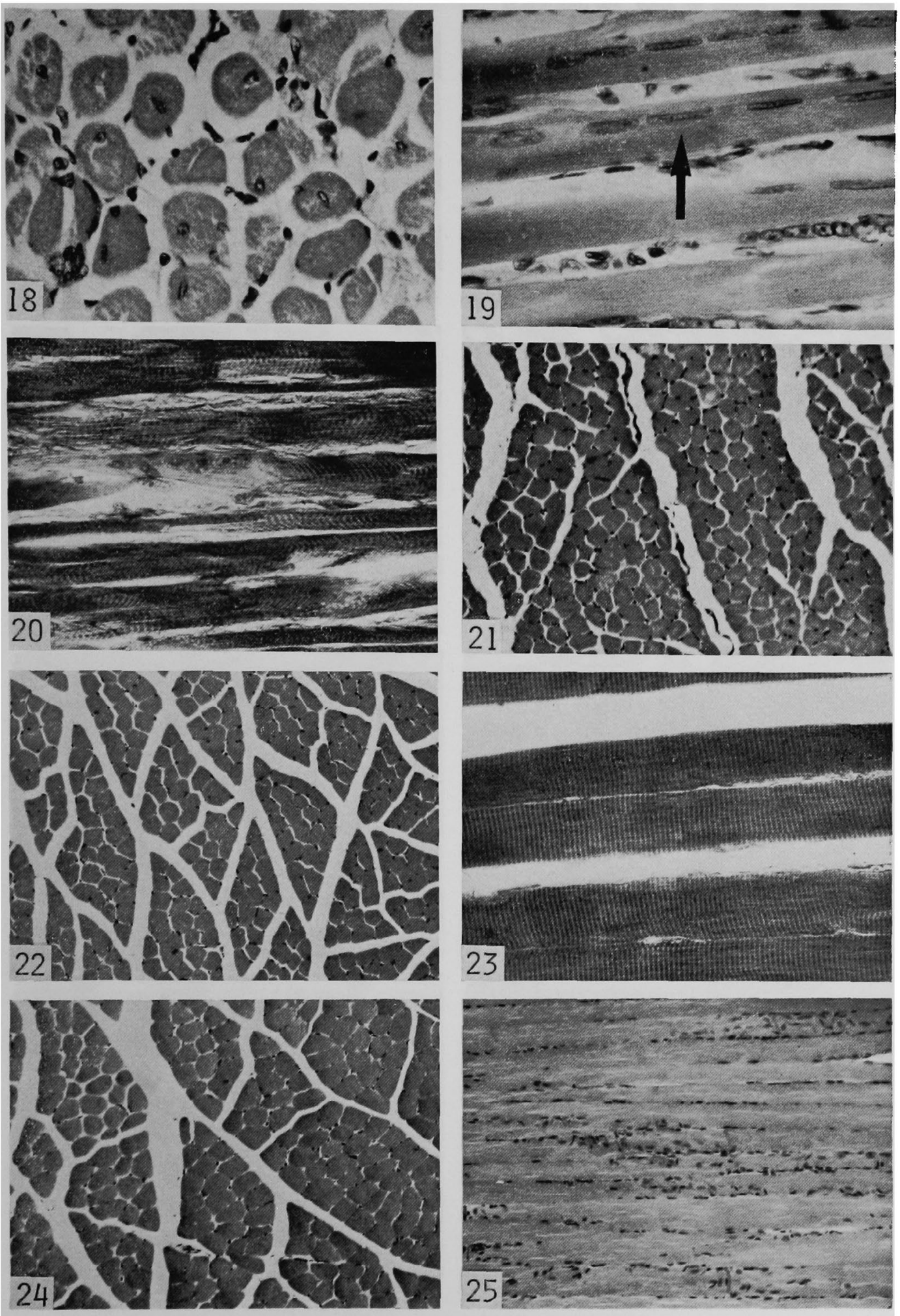


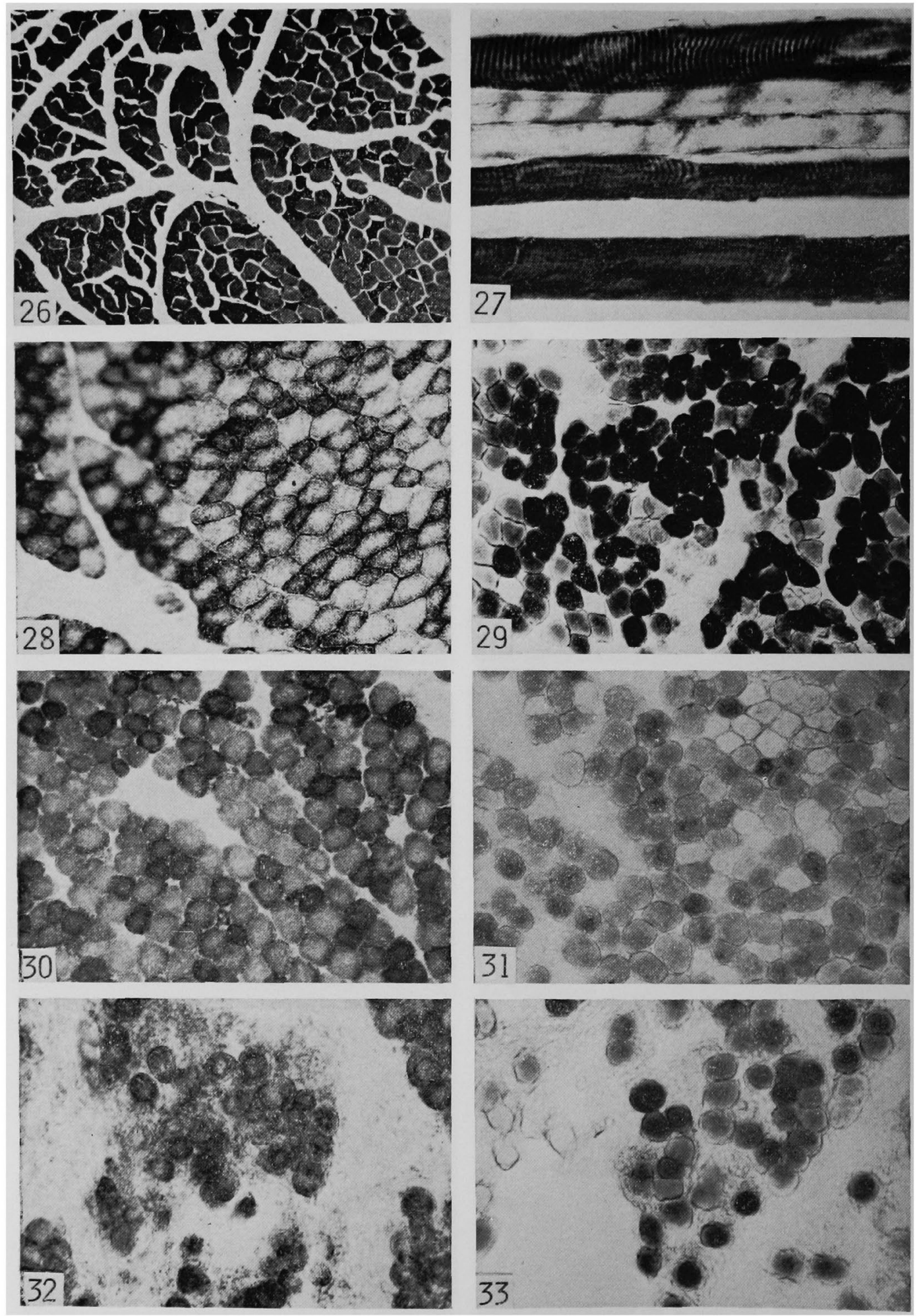



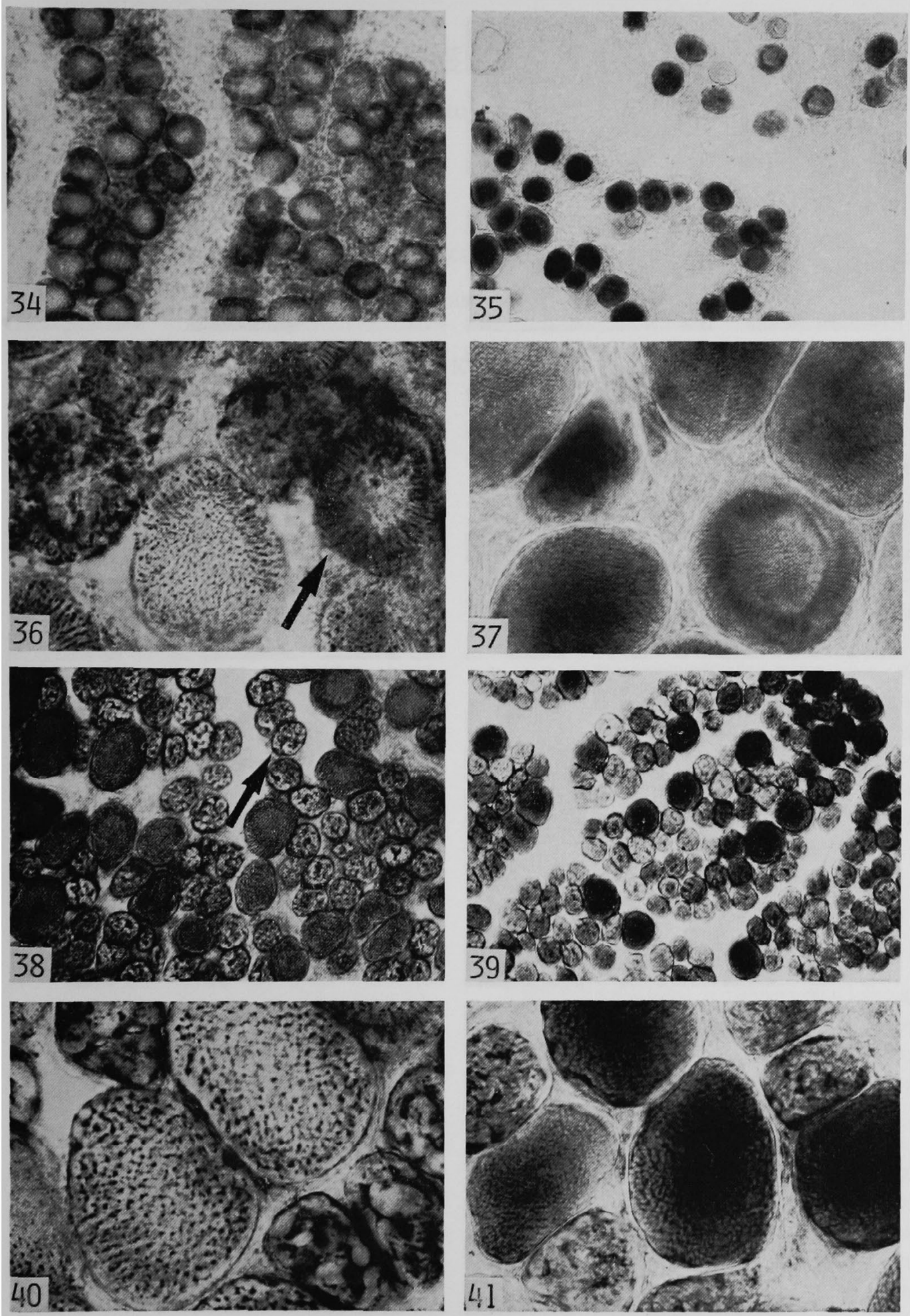

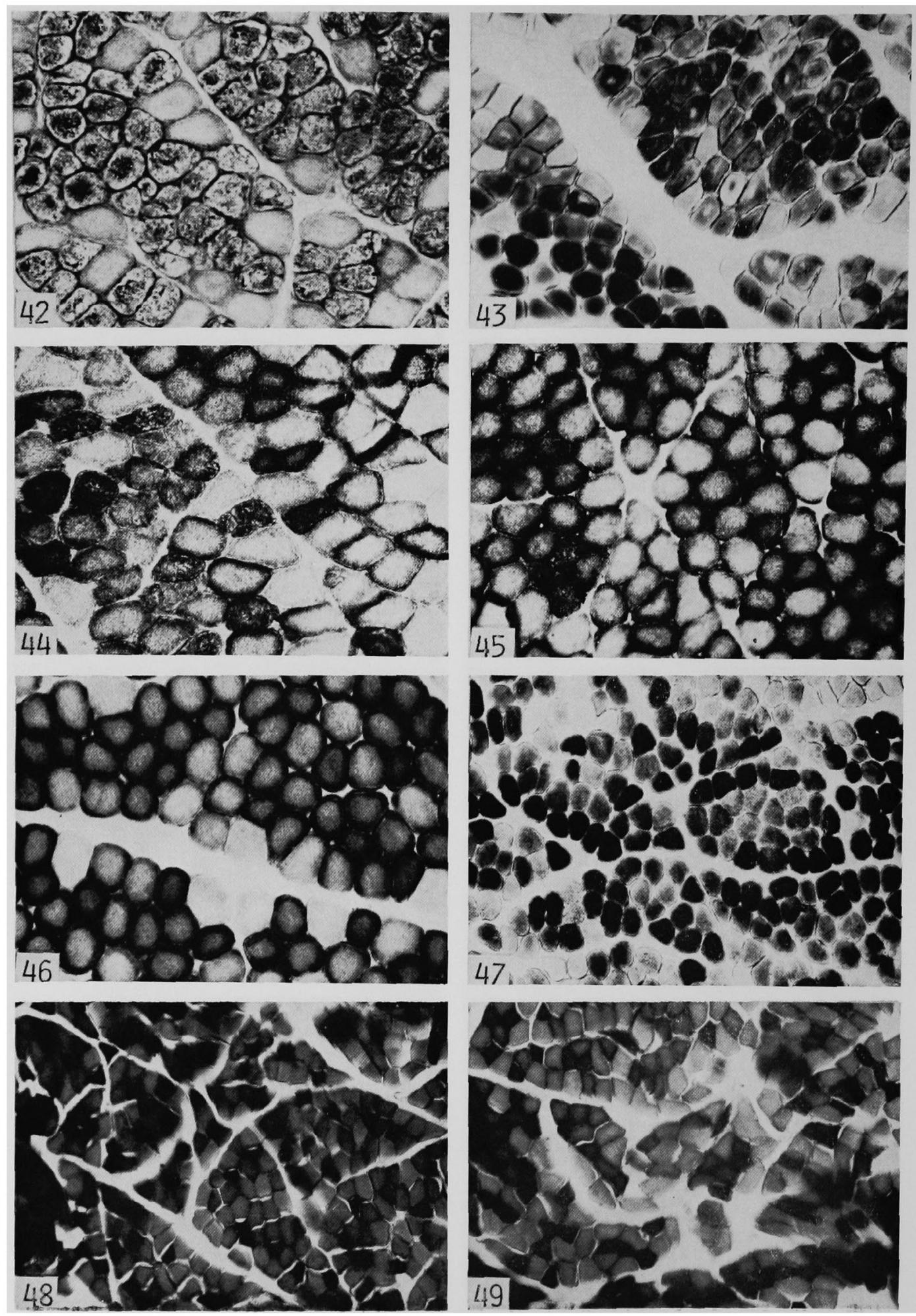